Word count: 12096 (including tables and figures)

\title{
Exploring the role of lean thinking in sustainable business practice: a systematic literature review
}

\author{
H.T.S. Caldera*, C. Desha and L. Dawes \\ Queensland University of Technology (QUT), Science and Engineering Faculty, School of Earth, \\ Environmental and Biological Sciences, 2-George Street, Brisbane, QLD 4001, Australia. \\ *savindi.caldera@hdr.qut.edu.au
}

\begin{abstract}
The shift towards sustainable manufacturing processes and products has influenced business organizations to improve their environmental performance and efficiency. 'Lean thinking' has evolved to 'lean and green thinking' as a targeted intervention for organizations to implement sustainable business models that reduce waste and improve material efficiency, and subsequently minimise costs. The lean and green concept however is still relatively new and it remains unclear for many as to how exactly lean thinking can contribute to the sustainability transformation of organizations. The objective of this research was to undertake a systematic literature review of how the implementation of lean and green initiatives could lead to sustainable business practice. This article includes an analysis of both conceptual and empirical research papers discussing various industrial contexts, and evaluation of: a) the impact of lean methods on environmental performance; and b) the variety of integrated lean and green models. The review highlights the ad hoc and limited use of lean thinking within corporate sustainability initiatives and the authors establish a 'lean and green matrix' that identifies opportunities to embed lean and green practices in five common work streams including waste, energy, emissions, water and chemical management. In addition to comparing different industries and their systems, this review provides a reference point for further investigation into lean and green practices. The findings contribute to the authors' research agenda that aims to develop a replicable system for holistically exploring strategies in corporate environmental management and prioritising the most appropriate lean methods. It is proposed that industrial practitioners could benefit from such a system, which could transform their organization's performance through well-integrated and aligned sustainable business practices.
\end{abstract}

Key words: lean thinking, sustainable business practice, lean and green, systematic literature review, sustainable business model, efficiency 


\section{Introduction}

Lean thinking is a business approach that delivers better value for customers by removing non-value-adding activities (Womack and Jones, 2010). The 'lean' concept evolved from the shop floors of Japanese manufacturer, Toyota Motor Corporation, which focussed on the reduction of waste in operations (Herron and Hicks, 2008; Ōno, 1988). The authors of the influential publication The Machine that Changed the World (Womack et al., 1990), coined the term "lean manufacturing", and "lean production", and furthered momentum behind the lean movement.

As the concept evolved, there was an increasing interest in the role of lean thinking processes in achieving sustainability outcomes (Fliedner and Majeske, 2010; Garza-Reyes, 2015). Over the last decade in particular, increasing pressures from government, regulatory bodies and society have led companies to align business practices with environmental sustainability principles. Sustainable business models such as the Management Helix (Smith et al., 2010) have been used as targeted approaches to incorporate sustainability concepts into decision making and to reduce negative impacts on both the environment and the society (Boons and Lüdeke-Freund, 2013; Stubbs and Cocklin, 2008). Within the manufacturing sector, 'lean manufacturing' is an emerging approach used in sustainable business models, to maximise material and energy efficiency (Bocken et al., 2014).

Over the last two decades, lean manufacturing processes evolved with implementation of pull mechanisms for efficient material flow (Womack and Jones, 1996), visualising waste through value stream mapping tools (Hines and Rich, 1997), having positive correlation with environmental activities and 'environmentally sustainable' initiatives (Chiarini, 2014; King and Lenox, 2001) and to have synergistic results on operational and environmental performance (Amani et al., 2015). However, there is still a gap in the literature about ways in which lean thinking can contribute to environmental outcomes and transform operations to 'sustainable business practice' defined as business behaviour that leads to a net overall increase in the different forms of capital associated with sustainable development" (Moser, 2001). Instead, much of the research has focused on exploring specific lean models and approaches in isolation, for example: reducing volatile organic compounds (Rothenberg et al., 2001), efficient energy use (Ball, 2015), reducing carbon footprint (Ng et al., 2015), and waste management (Kurdve et al., 2015; Maxwell et al., 1998).

Within this context, this review aimed to explore the evolving relationship between lean and green concepts. In the following sections, the authors present a summary of lean methods 
discussed in the literature and their effects on conventional categories of environmental sustainability work streams spanning waste, energy, emissions, water and chemical management. Within the lean and green context, this study considers the role of lean thinking in sustainable business practice, enquiring into, 'what are the lean methods that can be applied to environmental sustainability work streams', 'do these lean methods impact upon environmental performance' and 'what are the emergent lean and green models and its application?'.

These questions were addressed through a systematic literature review exploring how lean methods influence sustainable business practice, and how process efficiency and environmental performance could co-exist. Specific lean methods were identified and their impact on environmental performance evaluated. The authors provide an extensive review and categorisation on the conceptual and empirical types of lean and green models that are being used for business process improvement, which the authors anticipate will enable organizations to enhance the contribution of lean thinking to overarching sustainable business practice goals.

\section{Research Method}

The relationship between lean methods and 'green methods' (i.e. environmental sustainability initiatives) was evaluated to identify the potential for lean thinking to deliver environmental outcomes that contribute to the aspirations of sustainable business practice. Going beyond an expert review which would be limited by an ad hoc literature selection (Kitchenham et al., 2009), a systematic literature review was chosen to address the research questions, including an explicit, transparent and well-defined methodology to review research findings. The systematic review was conducted in five consecutive phases to ensure rigour and transparency of the method (Denyer and Tranfield, 2009b) as shown in Fig.1.

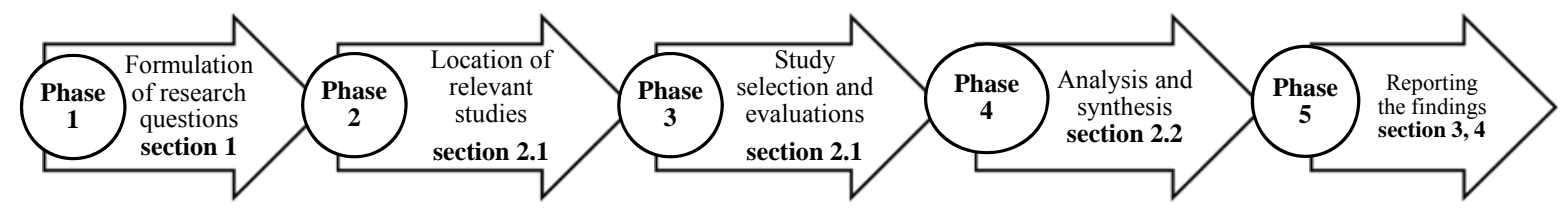

Fig. 1. Five phases of the literature review (phases adapted from (Denyer and Tranfield, 2009bp 681 -686))

Similar systematic literature reviews have previously been used in other related research fields including sustainability (Ceulemans et al., 2015) and in lean and green 
discourses (Garza-Reyes, 2015). Table 1 presents a summary of the selection criteria used for the review, which are expanded in Section 2.1.

Table 1. Detailed systematic literature review protocol adopted in five phases (phases adapted from (Denyer and Tranfield, 2009a; Garza-Reyes, 2015)

\begin{tabular}{|c|c|c|}
\hline $\begin{array}{l}\text { Literature review } \\
\text { phase }\end{array}$ & Methods & Tools \\
\hline $\begin{array}{l}\text { 1. Formulate } \\
\text { research question }\end{array}$ & $\begin{array}{l}\text { Derive a research question as } \\
\text { guiding statement to conduct the } \\
\text { study. Analyse highly cited journal } \\
\text { articles in lean and green research } \\
\text { field and identifying gaps }\end{array}$ & Backward and forward review \\
\hline $\begin{array}{l}\text { 2. Select sources and } \\
\text { locate studies }\end{array}$ & Define the relevant databases & $\begin{array}{l}\text { Science Direct (Elsevier), ABI Inform Global (ProQuest Direct), } \\
\text { EBSCOhost databases, Wiley Online Library (Wiley), Emerald Insight, } \\
\text { Scopus, Web of Science, Google scholar }\end{array}$ \\
\hline \multirow[t]{5}{*}{$\begin{array}{l}\text { 3. Select articles and } \\
\text { evaluate }\end{array}$} & $\begin{array}{l}\text { Define the time span of research } \\
\text { papers }\end{array}$ & $1995-2015$ \\
\hline & Define criteria and search strings & $\begin{array}{l}\text { Inclusion criteria- Lean terms with green, environment, sustainability, } \\
\text { eco-manufacturing etc. These terms were used in conjunction with } \\
\text { industry, manufacturing, business. Besides sustainability, the terms } \\
\text { 'waste management', 'chemical management', 'water management', } \\
\text { 'emissions management', 'energy management' }\end{array}$ \\
\hline & & $\begin{array}{l}\text { In this way an example of a search algorithm used was: title-abstract- } \\
\text { keywords ("lean thinking" OR "lean manufacturing" OR "lean } \\
\text { production") AND ("green" OR "environment*" OR "sustainab*") } \\
\text { AND ("waste management"). }\end{array}$ \\
\hline & & $\begin{array}{l}\text { Exclusion criteria- Unpublished working papers, industry reports, text } \\
\text { books, dissertations and magazines }\end{array}$ \\
\hline & Select relevant articles & $\begin{array}{l}\text { Backward and forward review, spanning peer reviewed journal papers } \\
\text { and conference papers (paradigmatic books were used to provide } \\
\text { background) }\end{array}$ \\
\hline \multirow[t]{2}{*}{$\begin{array}{l}\text { 4. Analysis and } \\
\text { synthesis of results }\end{array}$} & $\begin{array}{l}\text { Select a method to analyse the } \\
\text { qualitative data }\end{array}$ & $\begin{array}{l}\text { Concept map } \\
\text { Descriptive findings } \\
\text { Visual representation of data Thematic analysis }\end{array}$ \\
\hline & Code and synthesise data & NVivo software \\
\hline $\begin{array}{l}\text { 5. Interpret and } \\
\text { report the results }\end{array}$ & $\begin{array}{l}\text { Critically analyse literature and } \\
\text { encapsulate data from literature, } \\
\text { and link lean with sustainable } \\
\text { business practices }\end{array}$ & Summary tables, matrix table \\
\hline
\end{tabular}

\subsection{Extraction of relevant papers, timing and search terms}

Describing the review process along with selection criterion, search terms and databases ensures transparency of the method (Saunders et al., 2012). As an initial step in a systematic review of the literature it is important to establish the: (1) the literature sources [i.e., outlets to be searched (Webster and Watson, 2002)] and (2) the search strategy [i.e., the choice of search terms during the article selection process (Levy and Ellis, 2006)]. Sources of literature were located by checking the results of a defined search string in various publishers' electronic databases and thereby refine the articles relevant to the review scope. Articles were extracted from numerous electronic databases to acquire an in-depth understanding of the existing relationships between lean and green philosophies and potential areas for future research. As this is a transdisciplinary review it was important to examine both business and science databases to meet the review scope. Electronic databases included Science Direct (Elsevier), ABI Inform Global (ProQuest Direct), EBSCOhost databases, Wiley Online Library (Wiley), 
Emerald Insight, Scopus, Web of Science and Google scholar. Although the use of some databases created an overlap in the search results, this process ensured the validity of the methods since all of the information from business and science perspectives was captured.

Academically refereed, full-text journal and conference papers on the lean and green phenomena were sought using clearly defined search strings (key words from Table 1) in the environmental sustainability domain. Peer reviewed journals are the most useful of all primary and secondary literature sources and research-oriented conference proceedings are also very useful to critically review the literature (Saunders et al., 2012). These were therefore targeted in the search while unpublished working papers, industry reports, magazines and dissertations were excluded. The authors used the C-I-M-O (context-intervention-mechanism-outcome) framework (Briner and Denyer, 2012) to identify the inclusion and exclusion criteria of the search strings and as a strategy to evaluate the relevance of each item of literature.

The key terms 'sustainable business practice' and 'lean thinking' embrace an extensive range of sub-topics and therefore a significant number of search strings were required. The search terms were listed considering the phenomena which needs further investigation. The search strings such as '(lean thinking) AND (sustainab*), (lean) AND (green), (lean) AND (environment*)', etc. were used following the key words given in Table 1. These terms were used in conjunction with industry, manufacturing, business sector, model, framework in order to find articles covering the combination of these topics. Besides sustainability, the terms 'waste management', 'chemical management', 'water management', 'emissions management', 'energy management' were used since they are closely related to sustainability work streams. In this way an example of a search algorithm used was: '(lean thinking) OR (lean manufacturing) OR (lean production)' AND '(green) OR (environment*) OR (sustainab*)' AND '(waste management)'. This defined a specific scope for the search and exclusion of papers which did not include both search terms or link between lean and green. These encapsulated, synergistic relationships, methods, models and industrial case studies. Other critical concepts related to key words were also used in search strings to identify additional possible links.

Peer reviewed journal articles and conference papers published within the time period of 1996 to 2015 were sought given that this timeframe was aligned with the Global Cleaner Production and Sustainable Consumption Conference reflective timeframe and emergent themes and patterns of lean and green field over two decades were considered. Only limited research was published on lean and green topics before 1996 discussed "does lean mean 
green?" (for example Maxwell, 1993). The narrative on this topic grew significantly after 1996 when organizations began implementing ISO 14001 (Darnall et al., 2000) in late 1996 and moved towards environmentally conscious manufacturing. For example, in 1996, Florida (1996) identified integration of advanced manufacturing systems as a great opportunity for organizational improvement of environmental performance, and thereafter a growing body of literature about the lean and green concept became increasingly popular among academics, especially after 2010 when the number of publications increased significantly (Garza-Reyes, 2015).

A backward review process was conducted by going back to relevant citations used in the references of the extracted articles to determine preceding articles that were also related to the scope of the review. The forward review then determined subsequent articles which cited the extracted articles within the review theme by using Google Scholar citations. This served to access relatively extensive amount of literature (Webster and Watson, 2002). The saturation point was identified when the same articles began appearing repeatedly. All articles were also manually checked by reading the titles and abstracts to ensure the paper fit the study scope, so as to omit papers that did not address the lean and green concepts. For example, there were a number of articles that were omitted because they did not link lean thinking to environmental performance. Of 114 articles identified, 102 articles were chosen for inclusion in the final analysis. Microsoft Excel spreadsheets (Microsoft office 2013) and EndNote software (Version X7.5) were used as supporting tools for analysis. All identified articles were imported and saved in the EndNote software which aided in preventing the duplication of articles analysed. At the same time, in the Excel spreadsheet, the title, author, year, industry, origin of the country, journal or conference, and database of all articles were recorded.

\subsection{Analysis and synthesis}

The selected 102 articles were imported from EndNote as xml files to NVivo 11 software and saved in a 'source-phase 1' folder to analyse the content. Articles were defined in the (author, date) format to easily identify coded data. NVivo software is considered a powerful tool in managing, visualising and analysing qualitative data (Bazeley and Jackson, 2013). The software's ability to systematically manage data aided the process of thematic analysis to identify recurring themes and synthesize the results from this review (Barnett-Page and Thomas, 2009; Thomas and Harden, 2008). Given that the purpose of this research was to deliver a synthesized review on how lean thinking could be used as a targeted intervention for sustainable business practice, the analysis began with developing a-priori codification scheme 
around the questions of: what (what are the impacts of lean method on environmental performance?), who (different industries that lean and green concepts has been applied), why (benefits of implementing lean and green practices), and how (how to create lean and green models and what are the barriers faced?) as shown in Fig.2. The guidelines for the application of NVivo was defined by the authors based on coding rule book for this qualitative analysis and a preliminary classification (a-priori categorization) was made into a number of main groups. The NVivo flowchart of analysis is shown in Fig.2.

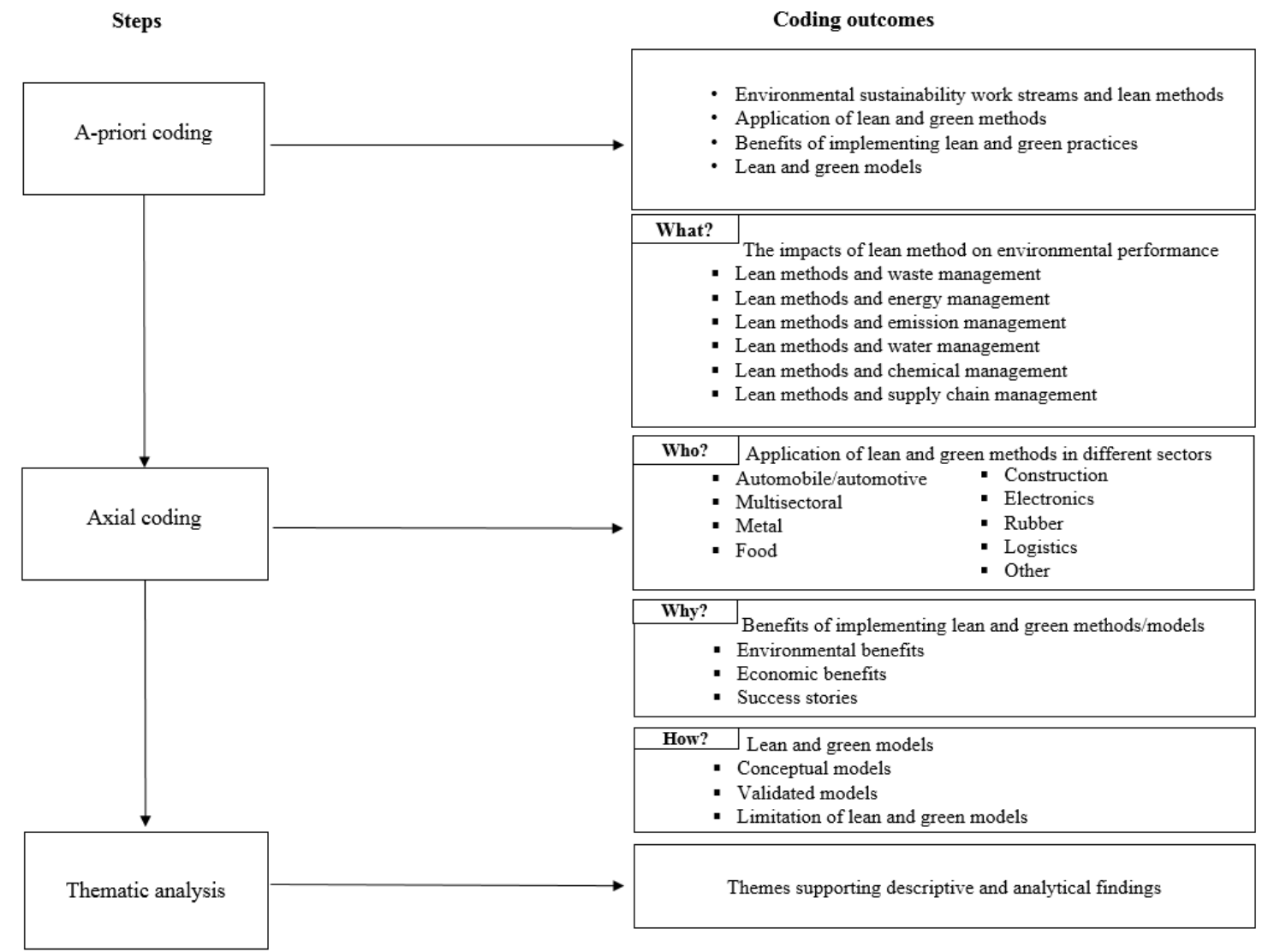

Fig. 2. Data analysis procedure (steps) used in NVivo and coding outcomes

The selection of these high level categories were supported by the underlying research question (Seidel et al., 2010) of 'what is the role of lean thinking in sustainable business practice'. During the first iteration, the relevant sentences were coded into a-priori nodes. Relevant data was then coded under the nodes, along with memo notes-to document initial impressions of topics, reminders and observations related to specific content and to trace the development of ideas. Data that did not align with the a-priori nodes were coded as new nodes. Axial coding was done thereafter, where data was put back together in new ways, identifying links and relationships between categories (Savin-Baden and Major, 2013) which led to a concept map representing the interconnections between current themes and themes for further 
exploration. Thematic analysis was used to identify emerging themes and patterns, and then refining those to inform the descriptive and analytical outcomes. Corroborative sessions among the research team established and confirmed the quality of the synthesis in terms of emergent themes and relevance of content to each node. Guidelines included in the coding rulebook ensured consistency and uniformity in interpretations. A rich combination of interpretation and analysis (Easterby-Smith et al., 2012) of these findings established the role of lean thinking in sustainable business practice. The findings of the thematic analysis are discussed in detail below, as descriptive findings and analytical findings.

\section{Descriptive analysis of findings}

Of the 102 articles selected for review, 88 articles (86\%) were journal articles and 14 articles (14\%) were conference papers. The range and frequency of reviewed journal articles are summarised in Fig.3. A substantial proportion 24\% (21 articles) of the journal articles were published in the International Journal of Cleaner Production. Approximately 6\% (5 articles) were published through Environmental Quality Management Journal, followed by the Benchmarking and Production Operation Management Journal with 3\% (3 articles). In addition to the articles shown in Fig.3, there were 40 other journal articles from 40 different journals.

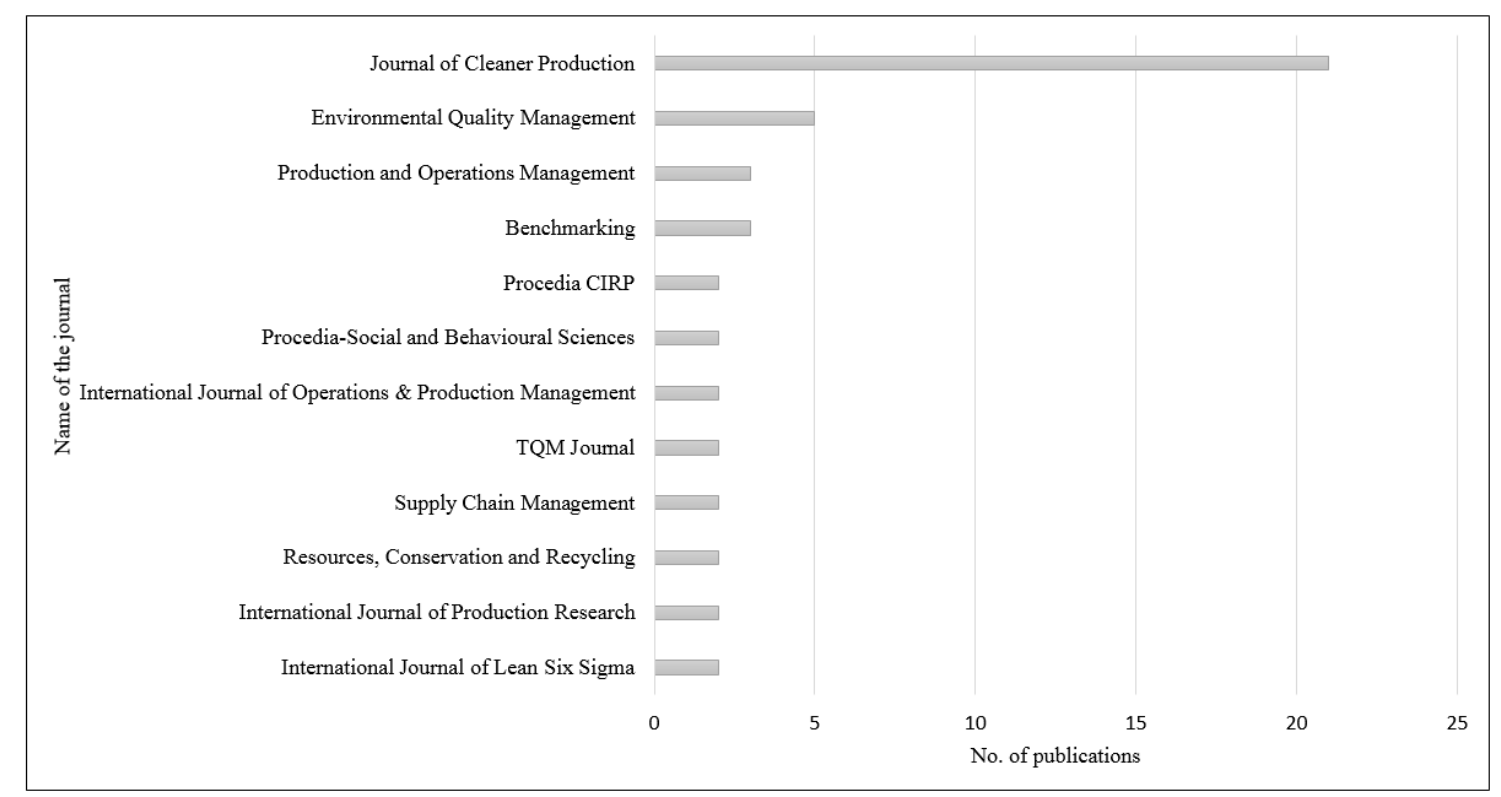

Fig. 3. Number of articles published in different journals

Fig. 4 presents a chronological summary of publications since 1996. As shown, there appears to be an increasing growth trend in articles on these topics from 2010 , with $81 \%$ of articles from the time period of 1996-2014 being published from 2010 and later. Publications 
from the year 2015 were not included in the graph in order to align with the time frame of the Global Cleaner Production \& Sustainable Consumption Conference 2015. These results highlight the relatively novel nature of this field of research, and how recent the emerging narrative on lean and green concepts.

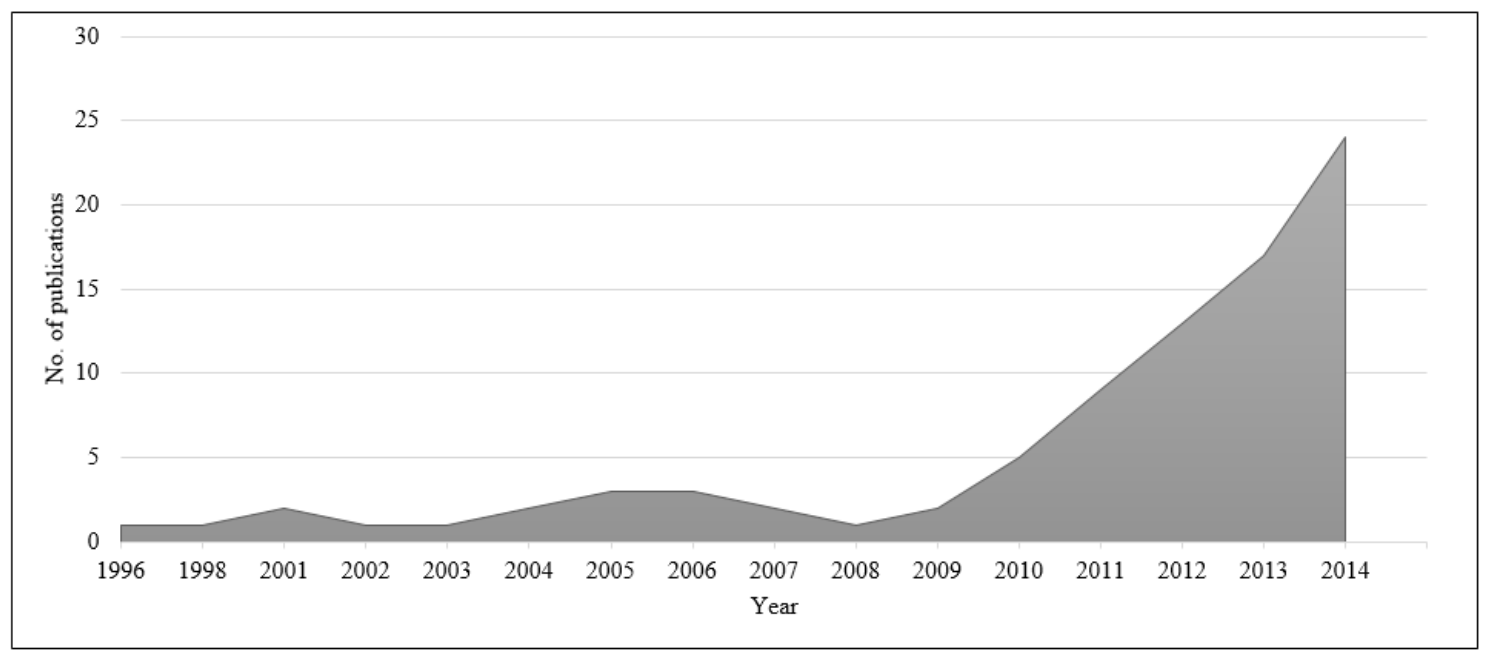

Fig. 4. Articles published over the period of 1996-2014

Although some articles (Azevedo et al., 2012; Salleh et al., 2012) disclosed the location of their case study, others only provided a generic name of the case study according to the type of the industry (Aguado et al., 2013). Given that first and second authors are generally considered the main contributors to research papers, these were used for the purposes of analysis to determine the geography of the publication content. Fig.5 shows the demographic distribution and number of the articles by the first authors of the 102 articles examined. The country associated with the second author was also analysed, and showed only minor differences in the proportions of publication by country. In most publications, both first and second author were associated with the same country. 


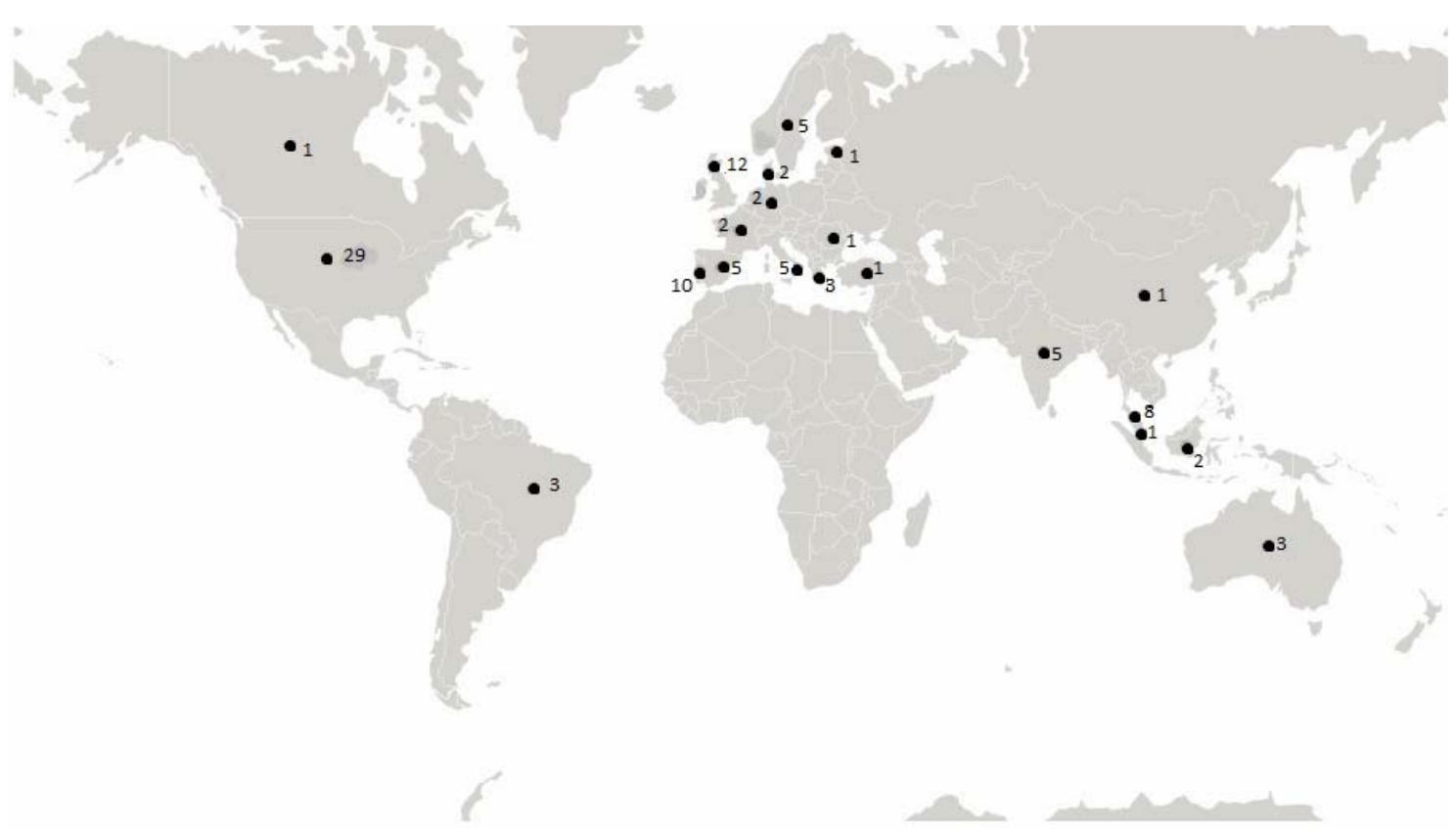

Fig. 5. Geographical distribution of research conducted on lean and green by first author

The distribution in developed and developing countries by economy (according to the UN country classification system, 2016) shows a higher percentage, $79 \%$ of publications originating from developed countries. The largest proportion of literature was originated from the USA (28\%), and the second highest originating from the UK (12\%). $21 \%$ of the publications evaluated and recurring themes originated from developing countries, specifically: Malaysia, India, Brazil, China, Indonesia, Singapore and Turkey. This distribution of publications may be a good indication that the research findings were also likely to be applied to industries in these same countries.

Fig. 6 presents the articles analysed according to their industrial application. Out of the 102 publications examined, 33 were theoretical papers, and 69 articles had a variety of industrial case studies or a variety of industries where the empirical data was gathered from. Industrial applications included: automotive, multi sectoral, metal work, food, construction, electronic devices, rubber, logistics and other. Multisector refers to publications which had more than one case study or the industrial application could be widely applied to multiple sectors (Piercy and Rich, 2015; Verrier et al., 2014). There were eight publications related to other industries and they consisted of single publications from: furniture, auto rental and leasing, education, furniture, paper and board, cyclic pallet system, manufacturing and service in general. 


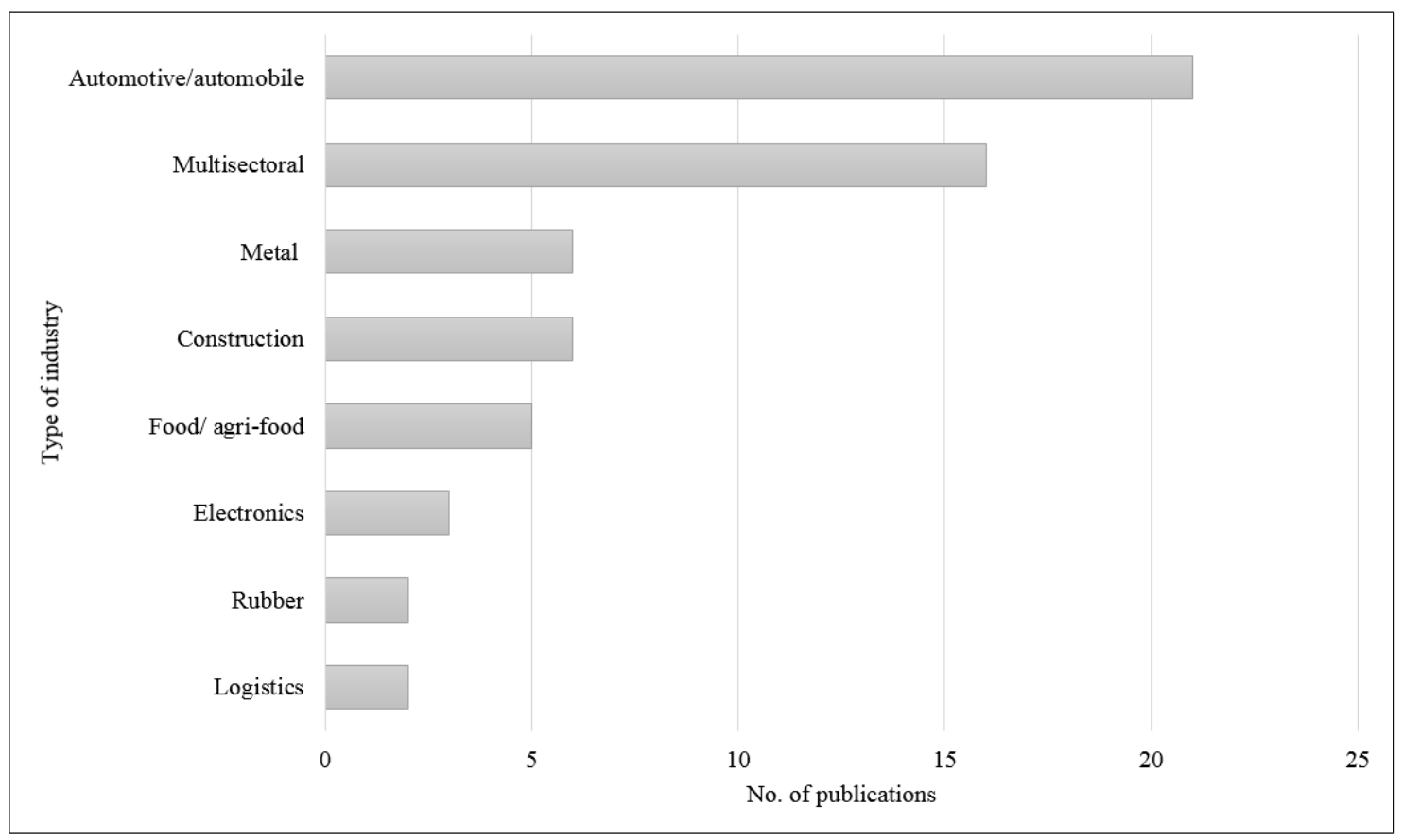

Fig. 6. Number of articles by the industrial application

Of the 69 articles discussing industrial case study applications, the highest number of applications were recorded in the automobile/automotive industry $(30 \%, n=21) .23 \%$ of articles were from multi sectors where the data was collected from more than one industrial application/multiple case studies in a single article. However there were also other articles emerging from additional sectors including: construction (Banawi and Bilec, 2014; Marhani et al., 2012; Marhani et al., 2013; Ogunbiyi et al., 2014; Song and Liang, 2011), metal (D'Errico et al., 2009), agri-food/food (Chaplin and Simon, 2014; Folinas et al., 2013), rubber (Govindan et al., 2014) and logistics (Cosimato and Troisi, 2015).

Fig.7 presents an emergent quadrant framework of lean and green literature highlighting dominant themes. The core concept of lean and green thinking is shown in the centre, around which two research streams of relationships and performance related literature are presented. For the purposes of this analysis, the articles were included in at least one category, and some articles are included in more than one category. The numbers shown in the adjacent boxes refer to relevant articles, corresponding to the list attached in Appendix A. For example, article number 70 (Chiarini, 2014) is considered relevant to several sub-categories: waste management and lean methods; energy management and lean methods; and the automobile sector. Thus this article and study is linked to all these thematics. 


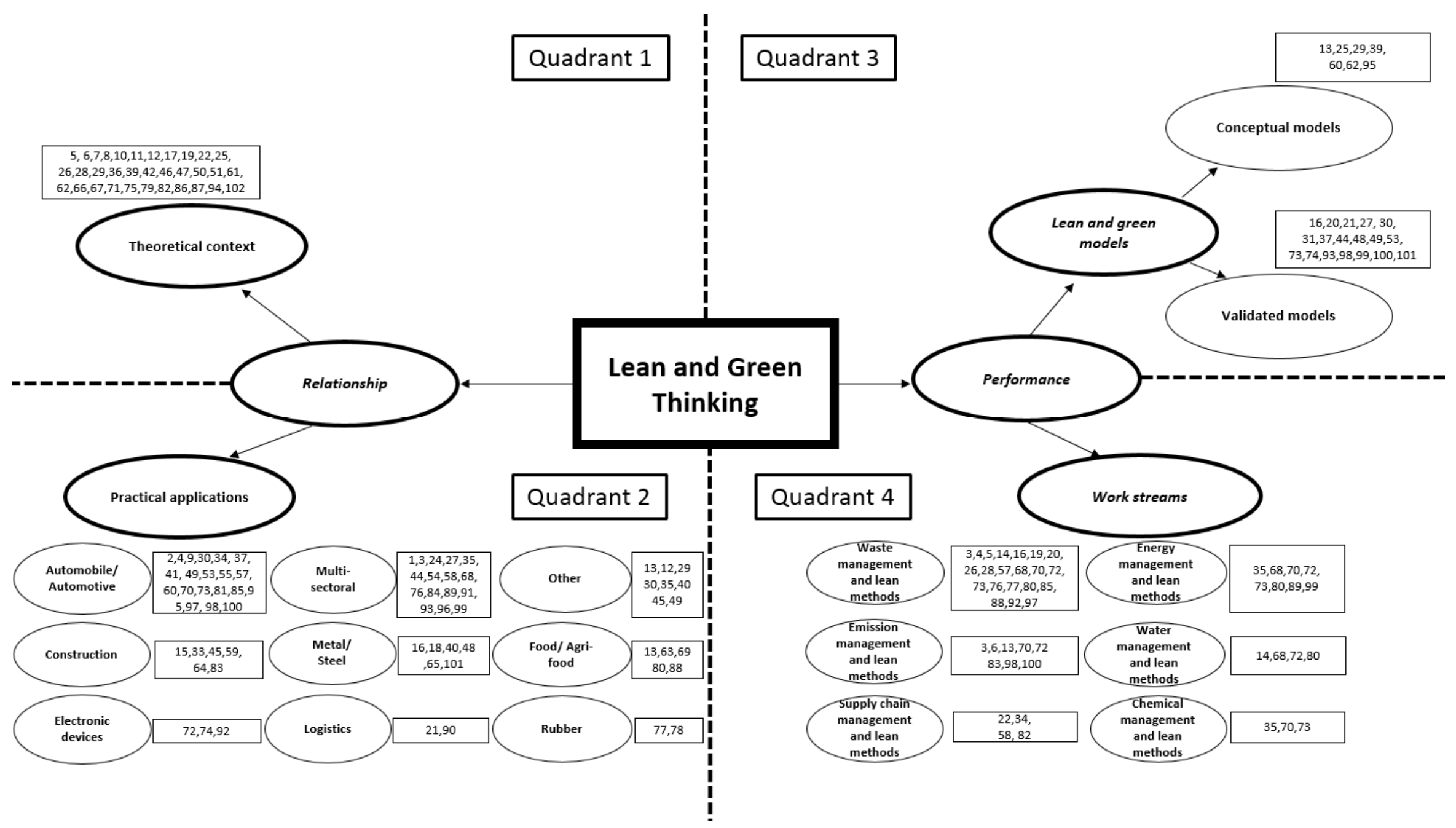

Fig. 7. Emergent quadrant framework of lean and green literature highlighting dominant themes. Numbers refer to the papers presented in Appendix A. 
The emergent quadrant framework established in Fig.7 highlights the key theoretical constructs found in the lean and green literature and the relationships between these constructs. Fox example Quadrant 1 and 2 presents the relationship between lean and green thinking based on applicability of lean and green strategies to theoretical contexts, and practical industrial context as explained in the descriptive analysis of findings, in section 3. Quadrant 3 and 4 presents literature on the impacts of lean and green thinking in terms of operational performance. Quadrant 4 presents literature on lean methods used to improve the environmental performance in the work stream of waste, energy, chemical, water and emissions, as described in section 4.2 under lean methods and environmental performance. Quadrant 3 presents the literature on lean and green models as described in section 4.2 under lean and green models.

Quadrant 3 and 4 indicate a degree of overlap in lean and green literature as the lean and green strategies implemented to improve environmental performance in the work streams were used as basic principles to develop lean and green models. Some of these models were augmented with numerical techniques such as optimisation and simulation.

Theoretical concepts of lean and green in Quadrant 1 and lean and green models in Quadrant 2 , have been presented in the lean and green literature to date, as being largely disconnected, and so highlights the need for the lean and green concepts to be better integrated.

Practical applications of lean and green strategies into different manufacturing sectors in Quadrant 2 and application of lean methods to sustainability work streams of Quadrant 4 have the most overlapping areas with similar contributions in lean and green literature as practical applications in the industry were evident in the work stream of waste, energy, chemical, water and emissions.

There is no overlap between Quadrant 1 and 2, where Quadrant 1 is based on theoretical papers, with theoretical contexts, conceptual models, and comprehensive literature reviews. In contrast Quadrant 2 is based on literature which had industrial applications to wide range of sectors including automobile, construction, metal, food, electronic devices, logistics, rubber, multisectoral and other sectors.

\section{Discussion}

Key findings emerging from the systematic literature review are detailed below, including what the authors refer to as a 'lean and green matrix'. The authors first present the overall findings on the relationship between lean and green, followed by a discussion of specific lean 
methods that impact work streams such as waste, energy, emissions, water and chemical management. The authors then synthesise the lean and green matrix based on positive impacts of lean and lean integrated methods on environmental sustainability work streams and, lean and green model types.

\subsection{Relationship between lean and green practices}

Lean and green thinking have emerged over the past two decades and so influencing in resource efficiency practices. Previous studies have primarily concentrated on the infusion of lean and green in terms of advanced production mechanisms and innovative methods for green manufacturing (Florida, 1996). The following analysis examined literature reflecting on last two decades of the lean and green practices.

\subsubsection{Cost reduction by the lean philosophy that contribute to sustainability}

Lean thinking is beneficial for sustainable manufacturing, particularly to enhance environment and economic outcomes (Hartini and Ciptomulyono, 2015). Lean methods help lower the marginal cost of reducing pollution by bringing down the cost of establishing remedial action for environmental pollution (King and Lenox, 2001). The application of lean thinking principles across the supply chain also allows businesses to improve efficiency, reduce lead time and cost (Womack and Jones, 1996).

Simultaneous implementation of lean and green methods impacts multiple parameters of operational performance and results in significant cost reductions (Miller et al., 2010). These benefits provides substantial potential to augment lean thinking within the aspirations of sustainable business practices, confirming what many authors have already claimed, that modern industry would achieve economic and environmental benefits by coupling lean and green.

\subsubsection{Waste reduction and pollution prevention goals of lean thinking that contribute to sustainability}

The literature reports that lean thinking methods stimulated continuous improvement of resource efficiency (Florida, 1996; Rothenberg et al., 2001), reduction of material and energy usage, which in turn leads to reduction and prevention of environmental pollution (King and Lenox, 2001; Larson and Greenwood, 2004). Business organizations with lean methods operating at a highly efficient level were able to prevent waste at the point of generation, rather than manage it once it had been generated (Florida, 1996; King and Lenox, 2001). 
There is consensus among researchers that: lean production has a positive correlation to waste minimisation and pollution prevention particularly in terms of co-existence of manufacturing process efficiency and environmental performance (King and Lenox, 2001).

Lean initiatives could then be expanded to address environmental waste generation and so improve environmental performance (Yang et al., 2011), while and green initiatives also positively impacting lean methods (Dües et al., 2013).

\subsection{Lean methods and environmental performance}

It is clear that lean methods have more positive impacts on improving environmental performance and may therefore facilitate sustainable business practice. Table 2 and 3 synthesizes the literature on lean methods and specific impacts of each method on environmental performance with quantitative and qualitative evidence.

\section{Table 2. Effects of lean methods on environmental performance with quantitative evidence}

\begin{tabular}{|c|c|c|}
\hline Lean methods & Author and year & $\begin{array}{l}\text { Impact on environmental performance with quantitative } \\
\text { evidence }\end{array}$ \\
\hline $5 \mathrm{~S}$ & $\begin{array}{l}\text { Vais et al. (2006), Fliedner (2008), } \\
\text { Chiarini (2014) }\end{array}$ & $\begin{array}{l}\text { Improve resource productivity, waste management and } \\
\text { energy efficiency. E.g.: Implementation of } 5 \mathrm{~S} \text { have reduced } \\
\text { mixed waste from } 30 \% \text { to zero in five companies analysed } \\
\text { (Chiarini, 2014). }\end{array}$ \\
\hline Cellular manufacturing & $\begin{array}{l}\text { Fliedner (2008), Bandehnezhad et al. } \\
\text { (2012), Chiarini (2014) }\end{array}$ & $\begin{array}{l}\text { Improve waste management and energy efficiency } \\
\text { E.g.: A reduction of } 68 \% \text { of energy consumption due to } \\
\text { reduced electricity for recharging the batteries of } \\
\text { the electric truck after implementing better layout and } \\
\text { categorising machines (Chiarini, 2014) }\end{array}$ \\
\hline $\begin{array}{l}\text { Lean supply chain } \\
\text { management }\end{array}$ & $\begin{array}{l}\text { Fliedner (2008); Simpson and Power } \\
\text { (2005), González-Benito and } \\
\text { González-Benito (2008), Miller et al. } \\
\text { (2010) }\end{array}$ & $\begin{array}{l}\text { Improve waste management across the network by } \\
\text { collaborating with the suppliers E.g.: collaborative supply } \\
\text { chain management eliminated } 7 \text { tons per year of volatile } \\
\text { organic compound (VOC) emissions, hazardous wastes, and } \\
\text { transportation-related impacts in its supply chain in a } \\
\text { painting process (Fliedner, 2008) }\end{array}$ \\
\hline $\begin{array}{l}\text { Total Productive Maintenance } \\
\text { (TPM) }\end{array}$ & $\begin{array}{l}\text { Fliedner (2008), Chiarini } \\
\text { (2014),Piercy and Rich (2015) }\end{array}$ & $\begin{array}{l}\text { Improve resource productivity, waste management, chemical } \\
\text { management and energy efficiency } \\
\text { E.g.: Effective scheduled maintenance of machinery reduced } \\
\text { the leakage level to almost zero (Chiarini, 2014) }\end{array}$ \\
\hline Value stream mapping (VSM) & $\begin{array}{l}\text { Simons and Mason (2003) Fliedner } \\
\text { (2008), Vinodh et al. (2011), Folinas et } \\
\text { al. (2013), Faulkner and Badurdeen } \\
\text { (2014), Brown et al. (2014) }\end{array}$ & $\begin{array}{l}\text { Identifying environmental impacts and assessing areas to be } \\
\text { improved and improve energy efficiency and waste } \\
\text { management E.g.: VSM identified areas for potential water } \\
\text { savings of } 170,000 \\
\text { gallons of water per day with little or no capital investment } \\
\text { (Fliedner, 2008) }\end{array}$ \\
\hline
\end{tabular}


Table 3. Effects of lean methods on environmental performance with qualitative evidence

\begin{tabular}{|c|c|c|}
\hline Lean methods & Author and year & $\begin{array}{l}\text { Impact on environmental performance with qualitative } \\
\text { evidence }\end{array}$ \\
\hline Employee involvement & $\begin{array}{l}\text { Maxwell et al. (1998), Rothenberg et } \\
\text { al. (2001), Soltero and Waldrip (2002), } \\
\text { Simpson and Power (2005) }\end{array}$ & $\begin{array}{l}\text { Employees engaging in effective implementation of } \\
\text { environmental sustainability initiatives }\end{array}$ \\
\hline $\begin{array}{l}\text { Adaptation of corporate } \\
\text { culture }\end{array}$ & Mollenkopf et al. (2010) & $\begin{array}{l}\text { Support from top management to implement sustainability } \\
\text { culture }\end{array}$ \\
\hline Buffer level & King and Lenox (2001) & Improve waste management and reduce pollution \\
\hline Kaizen events & $\begin{array}{l}\text { Rothenberg et al. (2001), Soltero and } \\
\text { Waldrip (2002),Vais et al. (2006), } \\
\text { Miller et al. (2010),Pampanelli et al. } \\
\text { (2014),Hong et al. (2014) }\end{array}$ & $\begin{array}{l}\text { Improve waste, water and chemical management, resource and } \\
\text { energy efficiency }\end{array}$ \\
\hline Quality circles & Maxwell et al. (1998) & $\begin{array}{l}\text { Innovative ideas to improve sustainability, waste reduction, } \\
\text { high employee engagement which leads to effective } \\
\text { implementation of environmental sustainability initiatives }\end{array}$ \\
\hline Inventory reduction & $\begin{array}{l}\text { King and Lenox (2001), Rothenberg et } \\
\text { al. (2001),Venkat and Wakeland } \\
(2006)\end{array}$ & $\begin{array}{l}\text { Improve resource productivity and waste management, reduce } \\
\text { energy usage and emissions by transport }\end{array}$ \\
\hline Lean product flow & Ball (2015) & Improve energy efficiency and thereby reduce emissions \\
\hline Pull approach & Fliedner (2008) & Improve waste management and energy efficiency \\
\hline Six sigma & Fliedner (2008) & Improve waste management and energy efficiency \\
\hline Pre-production planning & Fliedner (2008) & $\begin{array}{l}\text { Reduce waste by planning for a greener manufacturing } \\
\text { process }\end{array}$ \\
\hline
\end{tabular}

Table 4 summarises the literature on how "lean integrated methods" can reduce environmental impacts. These methods have been developed as an extension of the conventional lean methods shown above, by adding more environmental metrics and indicators which become topical over the last two years.

Table 4. Effects of lean integrated tools and practices on environmental performance

\begin{tabular}{|c|c|c|c|}
\hline Lean integrated methods & Author and year & Action & $\begin{array}{l}\text { Impact on environmental } \\
\text { performance }\end{array}$ \\
\hline $\begin{array}{l}\text { Sustainable value stream } \\
\text { mapping } \\
\text { (Sus-VSM) }\end{array}$ & $\begin{array}{l}\text { Faulkner and Badurdeen } \\
\text { (2014), Brown et al. (2014) }\end{array}$ & $\begin{array}{l}\text { Assess and monitor; energy, } \\
\text { water consumption and GHG } \\
\text { emissions, and areas of } \\
\text { improvement will be } \\
\text { suggested. }\end{array}$ & $\begin{array}{l}\text { Assess energy, water } \\
\text { greenhouse gas emissions, } \\
\text { noise levels, waste and water } \\
\text { measurements and address } \\
\text { areas of improvement }\end{array}$ \\
\hline Green value stream mapping & Marimin et al. (2014) & $\begin{array}{l}\text { Green value stream describes } \\
\text { seven areas of waste } \\
\text { generation as the over usage } \\
\text { of energy, water, resource } \\
\text { material, waste, transport, } \\
\text { emissions, and potential } \\
\text { damage to biodiversity }\end{array}$ & $\begin{array}{l}\text { Identify green waste other } \\
\text { than lean waste and } \\
\text { investigate on areas of } \\
\text { improvement }\end{array}$ \\
\hline Waste flow mapping & Kurdve et al. (2015) & $\begin{array}{l}\text { Reducing material losses and } \\
\text { inefficiencies in the handling } \\
\text { of materials and waste. }\end{array}$ & $\begin{array}{l}\text { Identify waste material } \\
\text { efficiency potentials }\end{array}$ \\
\hline
\end{tabular}

The lean methods associated with sustainable business practices under key work streams such as waste management, energy management, emissions management, water management, chemical management and green supply chain management are highlighted in 
the following section. In addition to these lean and lean integrated methods, sustainable lean initiatives such as "product research, design, \& development, building design and construction , indoor environmental control, facility and systems maintenance reclamation of resources and ethical and social considerations were identified by Fliedner (2008) claiming sustainability as the $8^{\text {th }}$ lean principle.

\subsubsection{Lean methods and waste management}

Industrial waste is the result of manufacturing activities and is discharged into the environment in the form of solid waste, waste water and emissions. Management of waste is important because improperly stored or discharged waste could cause negative impacts and create health, safety, economic and environmental problems. Industry generally adopts waste management practices like 'reduce, reuse and recycle' to minimise landfill waste (Schaper, 2002), and other environmental initiatives as end of pipe treatments. Many small enterprises, though, are resistant to being proactive and fail to embark on sustainability measures due to the major capital costs associated with changing raw materials or process designs, and they therefore instead implement ad-hoc solutions as required (Hillary, 2000).

'Lean manufacturing' as a business strategy focuses mainly on reducing non-value adding waste such as transport, inventory, motion, waiting, over production, over processing and defects (Ōno, 1988). The fundamental principle of lean manufacturing or lean thinking is to add more value to customers by omitting non-valued activities from the value chain (Florida, 1996). The main purpose is to eliminate waste and use resources efficiently which is directly linked to critical environmental issues such as pollution. The lean methods focus on achieving high quality standards throughout the manufacturing process and not merely to solve a problem when it arises, as such a short term measure is not usually sustainable in the long term. Similarly, environmental impacts of a manufacturing process should be anticipated beforehand so that proactive measures are adopted to prevent irreversible consequences, and are consistent with the cleaner production concept of addressing waste at the point of generation (King and Lenox, 2001; Sawhney et al., 2007).

There are numerous lean methods associated with environmental waste management spanning 5S, total productive maintenance, kaizen, quality circles, lean supply chain management, root cause analysis, lean six sigma, and pull approach (shown in Table 2 and 3). A holistic waste reduction programme, synergising green and lean programs, provides advantages in delivering better business results. Considering both types of waste - lean waste and green waste programs - to clean up the dirty dozen of waste: seven from lean programmes 
(transport, inventory, motion, waiting, over production, over processing and defects); and five from green programmes (water waste, hazardous waste, energy waste, solid waste, and greenhouse gases) were developed and these programs have synergistic effects on integrated waste management systems (Bergmiller and McCright, 2011). Identifying waste and establishing waste reducing techniques will impact the effectiveness of a firm's lean and green programmes (Bergmiller and McCright, 2009).

Different mapping tools such as green value stream mapping (Marimin et al., 2014), waste flow mapping (Kurdve et al., 2015), process mapping (White and James, 2014) do facilitate opportunities to observe and visualise the green waste point of generation and are also effective in evaluating environmental impact caused by the process activities. Amalgamated with life cycle assessment (LCA) these mapping tools can evaluate the potential environmental impacts associated with inputs and outputs at each phase of a product life cycle (from procurement of raw materials, material processing, use and discharge or recycling). The scope of the life cycle assessment (defining the start and end phase) can be defined according to the accessibility of data in the process. Product design and development model by Sorli et al. (2010) incorporated product life cycle and developed user-centric design and development while creating innovative and customised solutions for clients. Other specific tools that calculate the ecological footprint of a product are effective quantitative parameters to assess the area of land required to extract resources and emit waste when producing it. Such tools that incorporate lean methods and green waste management can yield better results in reducing financial costs and negative environmental impacts. Several researchers provided evidence on positive effects of lean and green combination on waste management (Folinas et al., 2014; Galeazzo et al., 2014) with some researchers using case studies to further demonstrate quantitative results in waste reduction (Amani et al., 2015).

Lean methods such as $5 \mathrm{~S}$, total productive maintenance and value stream mapping have contributed to improving resource efficiency and reducing waste. $5 \mathrm{~S}$ is conducive in creating a clean work environment, minimising waste by early detection of spills and leaks while encouraging employees to dispose waste systematically (Chiarini, 2014; Fliedner, 2008; Vais et al., 2006). Total productive maintenance (TPM) supports environmental management (Vais et al., 2006) and is advantageous in reducing impact caused by machine operations such as; reducing leakage of oil and emissions of dust, and chemical fumes to the environment (Chiarini, 2014). Value stream mapping is useful in determining environmental impacts in the manufacturing process and improving environmental performance through reducing scrap material and defects (Brown et al., 2014; Chiarini, 2014; Esfandyari et al., 2015). 
Manufacturers believe lean practice could improve their environmental performance but lacks a holistic approach in attaining synergistic results (Sobral et al., 2013). For example, industry does not capitalise on the association between value stream mapping and life cycle analysis. Value stream mapping was extended to a comprehensive methodology of 'sustainable value stream mapping' by recognising suitable metrics and methods to visually present environmental waste (Faulkner and Badurdeen, 2014). Sustainable value stream mapping addresses raw material waste, process water waste and energy waste under environmental metrics, not captured in traditional value stream mapping (Brown et al., 2014).

The Kaizen approach supports continuous improvement and facilitates activities in minimising material waste and pollution (Miller et al., 2010; Pampanelli et al., 2014; Vinodh et al., 2011). As an approach Kaizen can be integrated with Environmental Management Systems (ISO 14001) in sustainable business practices where continuous improvement plays a key role. Quality circles play is vital in identifying process issues from employees and getting innovative solutions from them (Maxwell et al., 1998). Participation of people is considered to be a critical factor in implementing lean management system (Amani et al., 2015; King and Lenox, 2001; Maxwell et al., 1998; Soltero and Waldrip, 2002). Likewise, in environmental management "people involvement" is imperative in carrying out environmental initiatives (Rothenberg et al., 2001), a process useful in effective implementation of initiatives as employees have ownership in implementing their own ideas. Even in sustainable business practice, quality circles are useful to analyse problems by brainstorming or using cause effect diagrams." Champions to drive initiatives could be selected from these lean quality circles and sustainability circles based on the creativity of the solutions they present. Such a strategy would be successful if these employees, ecopreneurs, champions could be recognised and rewarded for implementing those solutions and the execution of their ideas could be assured (Sarah and Clifford, 2007; Stubbs and Cocklin, 2008). Lean thinking can be considered as a business model archetype of sustainable and social manufacturing area as well, given its role in actively empowering people to generate new ideas and engaging them in implementing new initiatives.

\subsubsection{Lean methods and energy management}

Planning and efficient use of energy in an organization leads to resource efficiency as well as economic savings. Energy management is connected to environmental management systems and requires behavioural changes in people to reduce wasteful energy usage. Energy efficient technologies such as installing energy efficient appliances, improving lighting systems while maximising natural light, green building designs, zero emission transport, use 
of renewable energy solutions such as hydro, wind and solar are all important in efficient management of energy (Moscardo, 2013).

Lean thinking is a continuous improvement approach for energy efficient manufacturing for monetary savings and reduced negative environmental impacts (Garetti and Taisch, 2012). A number of lean methods influence energy management such as cellular manufacturing, lean product flow, total productive maintenance, $5 \mathrm{~S}$, value stream mapping, kaizen and sustainable value stream mapping where some provide a positive correlation between lean practices and efficient use of energy (Rothenberg et al., 2001). Chiarini (2014) established positive effects of lean methods on energy consumption through an empirical research conducted in a European motorcycle component manufacturer. Cellular manufacturing leads to a decrease in energy by means of lower set up times and lesser product changeover, with reduced inventories demanding floor spacing that allows for a reduction in energy consumption (Bandehnezhad et al., 2012; Chiarini, 2014). Little importance has been identified for lean integrated tools such as sustainable value stream mapping tools as an energy metric to monitor and evaluate the energy usage in processes (Brown et al., 2014; Faulkner and Badurdeen, 2014).

A positive correlation between $5 \mathrm{~S}$ and energy efficiency due to reduced space in manufacturing functions was proven through an empirical research study conducted by Chiarini (2014). The use of total productive maintenance also showed a decreased energy consumption (Chiarini, 2014) and with the use of lean tools such as Kaizen (Pampanelli et al., 2014), and value stream mapping (Folinas et al., 2014), systematic approaches have been suggested to significantly reduce energy consumption. Ball (2015) investigated the effects of lean product flow on energy consumption and found that using cluster batches minimise losses between productions and enables processes to run efficiently. However, strategies to reduce energy consumption such as reuse of the heat produced as waste in one process for another process, could be restricting the production schedule (Ball, 2015). Operation flows in the lean product flow could be infused with sustainable designs by considering maximum utilisation of natural lighting and ventilation by installing windows and skylights. In the neo classical economic system, the primary objective of business is profit maximisation (Stormer, 2003), therefore quantifying the benefits in monetary terms is appealing to organizations. With the increasing prices in fuel and energy, creating the need for substantial energy reductions leads to a win-win situation in both economic and environmental performance in business organizations. 


\subsubsection{Lean methods and emissions management}

Emissions management is a common sustainability work stream used in organizations as a strategy to reduce carbon dioxide and other emissions from their manufacturing processes. Nearly $31 \%$ of global primary energy is consumed by the manufacturing industry (IEA, 2007) and can be directly linked to carbon emission and climate change, a global environmental concern. The combustion of fossil fuel such as coal, fuel and natural gas causes emission of carbon monoxide, sulphur dioxide, nitrous oxide and heavy metals make it essential to adopt clean technologies and shift towards renewable energy options. That means that emissions management strategies and tools such as carbon footprint analysis, strategic assessment of climate risks and opportunities, energy efficient measures, renewable energy use, emissions trading, and investing in carbon credits (Moscardo, 2013) all need to be practiced. Environmental taxes especially carbon tax have encouraged many organizations to reduce their carbon footprint. Carbon management as one emission management strategy directly impacts economic and environmental performance in business organizations (Azevedo et al., 2012). For example when environmental taxes were imposed on businesses in the Scandinavian countries such as Sweden, Norway and Denmark, the increasing fuel prices, led to increased prices in products (Ekins, 1999) This tax was enacted to reduce greenhouses gas emissions as a mitigating measure for climate change.

Empirical evidence confirms that lean methods do impact the reduction of emissions (King and Lenox, 2001), specifically volatile organic compounds (Rothenberg et al., 2001). However, few lean methods have been applied to emissions management compared to waste management. The three key lean methods that have been associated with emissions management are the flow principle, total productive maintenance and value stream mapping. The flow principle decreases energy consumption and thereby reduce gaseous emissions (Ball, 2015). Total productive maintenance reduces dust emissions and chemical fume into the environment (Chiarini, 2014). The third lean method used to manage emissions is the value stream mapping (VSM) tool which is used to identify non-value adding components in the manufacturing process and well trained staff are necessary for a smooth workflow if VSM is to reduce in carbon emissions (Wu et al., 2013). VSM was also identified as an effective lean tool to identify factors affecting total emissions in a specific supply chain and also to reduce waste measured in terms of carbon emissions (Folinas et al., 2013). Value stream mapping has been used extensively and integrated with Kaizen to develop 'A carbon- value efficiency methodology' to make significant improvements in carbon value efficiency and reduction of carbon footprint ( $\mathrm{Ng}$ et al., 2015). This value stream mapping has been effective and extended 
to 'sustainable value stream mapping' by using energy metrics which are directly linked to the emission of greenhouse gases (Faulkner and Badurdeen, 2014). Sustainable value stream mapping, can lead to end-to-end (from raw material to product) carbon dioxide reduction (Simons and Mason, 2003).

While some lean methods have been used globally in emissions management, not all lean methods are green. For example, frequent replenishment of inventory in lean supply chains raises the carbon dioxide emissions due to increased transport (Venkat and Wakeland, 2006), demonstrating that not all lean tools and practices are necessarily green. Organizations should carefully choose lean tools when integrating with sustainable business practice. Rothenberg et al. (2001) believes that trade-offs between lean and green are unavoidable and pointed out for example that, painting cars in batches of a similar colour for example will minimise emissions. This lean approach however uses spray paint to obtain better quality and efficiency, however also has negative effects on the environment. Some organizations in the automotive industry have shown interest in compromising lean practices to mitigate their emissions (Rothenberg et al., 2001) which highlights the need to apply lean methods to streamline manufacturing processes, and identify potential areas to harness the sustainable business practice.

\subsubsection{Lean methods and water management}

Water is a scarce resource and should be carefully consumed to fulfil both immediate needs and long term environmental sustainability. Better management of water demands 'water efficiency' approaches such as reducing pollution during the manufacturing process, increasing the capacity of water for reuse, and reduce waste water in industries. Raising awareness of sustainable water management among employees and providing training will ensure appropriate "water efficiency" and "pollution prevention" approaches (Byers et al., 2010).

There are a limited number of lean methods used for efficient water use, however Kaizen (continuous improvement practices) and value stream mapping are identified as being currently in use. Kaizen focus and its workshops and training programs have caused people to change their attitudes toward proper housekeeping in organizations and the 3Rs of reduce, reuse and recycle (Vais et al., 2006). Inculcating such a culture means employees are motivated to use recycled water and to responsibly consume and discharge water. An extended value stream mapping technique measured water consumption (Folinas et al., 2014) but lacked proper monitoring and water metrics. The new 'sustainable value stream mapping' method monitors the water consumption level during manufacturing activities and identifies areas to be evaluated and considered for improvement (Brown et al., 2014; Faulkner and Badurdeen, 
2014). Integrated lean and sustainable water management practices could be further improved by amalgamating sustainable corporate environmental initiatives such as assessment of water consumption (e.g.: central water metering, sub metering), sustainable sourcing of water, treatment of waste water, re-use of treated waste water for other purposes such as gardening and toilet flushing, installing water efficient fittings, rain water harvesting, drip irrigation for landscaping as well as raising awareness and training employees.

\subsubsection{Lean methods and chemical management}

The excessive use of toxic substances in industrial processes causes a major threat to human health and the environment making it critical to examine the health and safety risks and environmental hazards of chemicals used in the manufacturing process as well as chemicals used in the workplace. For example, the restricted substance list (RSL) of chemicals contains a list of chemicals and substances toxic for human health and environment and encourages the industrial practitioners in apparel and footwear industry to remove such substances from their products and processes (Das, 2013). Organizations should ensure safety of people and the environment through proactively understanding and prudently selecting every chemical and raw material used in their manufacturing process.

There is minimal use of lean methods in chemical management where only a few approaches such as 5S, Total productive maintenance and Kaizen are currently in use. 5S as an approach for organizing the work environment in a better way, and to identify spills and leaks to reduce chemical and material usage (Bandehnezhad et al., 2012). Incorporating 5S principles such as sorting, set in order and standardising are part of $5 \mathrm{~S}$ with chemical management initiatives such as assessing material safety data sheets (MSDS) of each chemical used in the process, checking its risk while comparing against the restricted substance list of that particular industry and making a chemical management plan would improve the role of lean thinking in sustainable chemical management. Total productive maintenance is used to reduce impact on machines such as oil leakages, emissions of dust and chemical gases to the environment (Chiarini, 2014). Implementing Kaizen events led to reduction of general chemical products consumption when applying lean and green model for production cell (Pampanelli et al., 2014).

The Kaizen is an approach based on continuous improvement and this concept is the underlying principle for environmental management system, and confirms the similarities in the core concepts of lean and green management. 


\subsubsection{Lean methods and green supply chain management}

The principles of lean, green and supply chain management (flow of goods and services) have been examined by several researchers to establish links between lean, green and supply chain management. A growing body of literature has established: drivers, barriers, converging and contradictory factors and the role of lean supply chain management in implementing environmental sustainability initiatives across the supply chain (Mollenkopf et al., 2010); relationships between lean management, supply chain management and sustainability (Martínez-Jurado and Moyano-Fuentes, 2014); a model to analyse the effect of green lean upstream supply chain management on sustainable development (Azevedo et al., 2012) and possible synergistic effect between environmental and quality/lean practices in supply chains (Wiengarten et al., 2013). The role of lean, green supply chain management models were established in manufacturing as well as in service sector.

Table 5 presents a matrix distilled from all of the lean methods discussed in section 4.2 of this analysis, and represents the positive impacts of lean and lean integrated methods on a specific environmental management work streams. The black dots represent the availability of a particular lean tool to improve an environmental management work stream based on the findings and discussion above. 
Table 5. Lean and green matrix on positive impacts of lean and lean integrated methods on environmental sustainability work streams

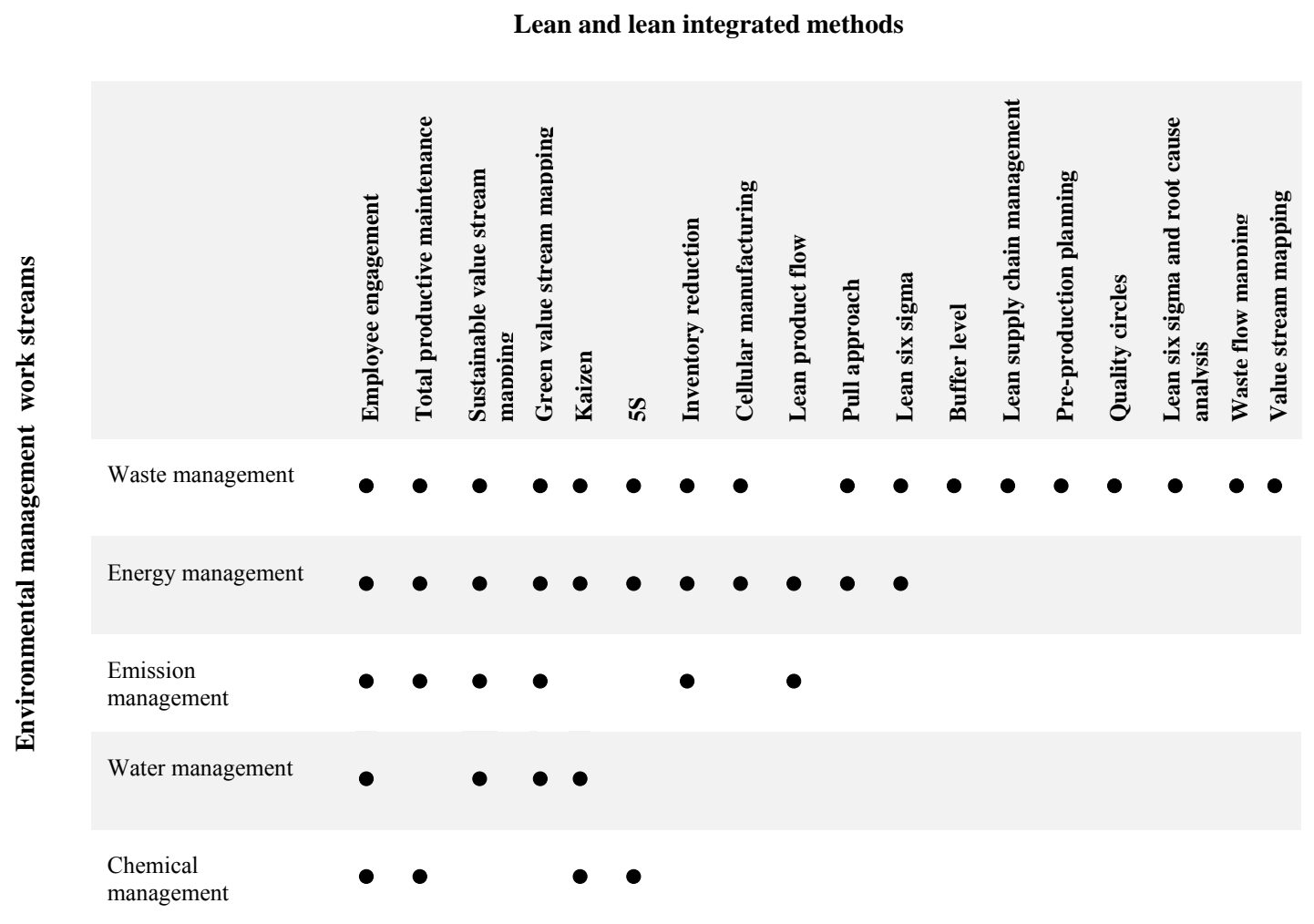

\subsection{Lean and green models}

A sustainable business model is described as a business model that bring about competitive advantage by providing excellent customer value and is instrumental in the sustainable development of the company as well as the society (Lüdeke-Freund, 2010). Strategy definition, organizational support, intrinsic and extrinsic motivation were identified as key enablers in implementing sustainability business practice in business organizations (Seidel et al., 2010). Sustainable business modelling benefits from a value mapping tool, which proposes three forms of value such as value captured, missed or wasted and opportunity (Lenssen et al., 2013). Environment, society, customer and network actors are identified as four stakeholder groups in this value mapping tool which encapsulates the firm's perspective as well as stakeholder views to give a better interpretation of the value proposition (Lenssen et al., 2013). 'Lean thinking' is targeted intervention for profit-dominated organizations to implement sustainable business models to define strategy, reduce waste, improve material efficiency and create value. Value stream mapping is an efficient lean tool used to identify material flow and waste in sustainable manufacturing processes and thereby evaluate areas for improvement to deliver better value for customers (Rother and Shook, 2003). Lean and green system model together create a structured and holistic mechanism for making a business green (Zokaei et al., 2013) 
and could therefore be used as a potential sustainable business model to harness the best outcomes in an organization's economic and environmental performance. Reduction of raw materials, utility footprints and cost are significant benefits of adopting lean and green practices (Sobral et al., 2013; Zokaei et al., 2013).

There is an increasing amount of literature on lean and green models integrating lean and green philosophies to develop conceptual models, some of which were validated with case studies. The attempts to conceptualise and numerically construct optimisation or simulation models are encapsulated in Table 6. At the outset of developing green and lean models it is important to identify the overlapping sections of both practices that achieve the best cumulative results in environmental and economic performance (Dües et al., 2013). Waste, waste reduction techniques, people and organization, lead time reduction and supply chain relationship are some of the common attributes which intersect the two subsets of lean and green paradigms (Dües et al., 2013). A number of researchers used these common attributes to develop conceptual models, with some validating their conceptual models by obtaining empirical data.

This section of the review analysed 25 articles on lean and green models which included six conceptual models and 18 validated models (shown in Table 6). In most cases the conceptualised models were validated in a specific industrial context - the majority of validated models were from the automobile and automobile/automaker supply chain industry (32\%). This high proportion in the automobile and manufacturing field can generally be understood as the lean manufacturing system/Toyota manufacturing system originated from the automobile context. Successful implementation of lean manufacturing systems in these industries indicated Toyota Corporation's leadership in incorporating environmental sustainability into lean thinking. This also indicates a significant emergence in the lean-green supply chain management field as also evident in the extensive reviews of Martínez-Jurado and MoyanoFuentes (2014) and Mollenkopf et al. (2010). 
Table 6. A summary of lean and green models and approaches (found in the literature)

\begin{tabular}{lll}
\hline $\begin{array}{l}\text { Proposed model } \\
\text { (authors, year) }\end{array}$ & $\begin{array}{l}\text { Model type } \\
*\end{array}$ & Context \\
\hline $\begin{array}{l}\text { Simple generic supply } \\
\text { chain model (Venkat and } \\
\text { Wakeland, 2006) }\end{array}$ & Conceptual & $\begin{array}{l}\text { Generic food } \\
\text { supply chain }\end{array}$ \\
\hline $\begin{array}{l}\text { Environmentally Lean (En- } \\
\text { Lean) methodology } \\
\text { (Sawhney et al., 2007) }\end{array}$ & Validated & Metal working \\
\hline
\end{tabular}

Limitation

Simulated the generic supply chain which demonstrates the conflicts between lean and green, trade-offs and other opportunities to optimise process En-Lean method to facilitated the developing association of lean practices and environmental considerations for a specific process by using Use of HTML and JavaScript codes to integrate lean and environmental practices taking multiple environmental measure for consideration

\begin{tabular}{llll}
\hline $\begin{array}{l}\text { Simulation model (Esmemr } \\
\text { et al., 2010) }\end{array}$ & Validated & $\begin{array}{l}\text { Shipping and } \\
\text { logistics }\end{array}$ & $\begin{array}{l}\text { Simulated the process to decide } \\
\text { optimum number of machines to } \\
\text { minimise the environmental impacts }\end{array}$ \\
\hline $\begin{array}{l}\text { Integrated lean tools and } \\
\text { sustainability concepts with } \\
\text { discrete event simulation } \\
\text { modeling (Miller et al., }\end{array}$ & Validated & Furniture & $\begin{array}{l}\text { Investigated manufacturing process } \\
\text { by using mathematical optimization } \\
\text { 2010) }\end{array}$ \\
$\begin{array}{l}\text { to select appropriate supplier to } \\
\text { minimise the transportation distance } \\
\text { (reduce carbon footprint) and }\end{array}$ \\
$\begin{array}{l}\text { Optimization model } \\
\text { (Mashaei et al., 2011) }\end{array}$ & Validated & $\begin{array}{l}\text { Cyclic pallet } \\
\text { system }\end{array}$ & $\begin{array}{l}\text { Used of optimisation principle to } \\
\text { reduce energy usage in pallet system }\end{array}$
\end{tabular}

Focused more on effectiveness and limited focus on lean and green dimensions to improve efficiency Limited generalizability to other industrial context.

\begin{tabular}{|c|c|c|c|}
\hline $\begin{array}{l}\text { Interoperability analysis } \\
\text { model (Espadinha-Cruz et } \\
\text { al., 2011) }\end{array}$ & Validated & Automotive & $\begin{array}{l}\text { Assessed business interoperability } \\
\text { and suggests actions to minimise } \\
\text { supply chain issues }\end{array}$ \\
\hline $\begin{array}{l}\text { Model incorporating lean } \\
\text { and green supply chain } \\
\text { into a performance } \\
\text { measurement system, using }\end{array}$ & Conceptual & Supply chain & $\begin{array}{l}\text { Used of balanced score card } \\
\text { approach to integrate lean and green } \\
\text { supply chain into a performance } \\
\text { measurement system }\end{array}$ \\
\hline
\end{tabular}

Limited generalizability to other industrial context. The mechanical errors and complexity of time is not captures in the study (due to variable permutation matrix)

Limited applicability and validity to real world large scale practices

Minimal validation for the real world context

measurement system, using

measurement system

approach (Duarte et al

2011)

\begin{tabular}{|c|c|c|c|}
\hline $\begin{array}{l}\text { A conceptual model with } \\
\text { lean, agile, resilient and } \\
\text { green practices and supply }\end{array}$ & Conceptual & Supply chain & $\begin{array}{l}\text { Identified the synergistic effects, } \\
\text { divergences caused by lean, agile, } \\
\text { resilience and green paradigm }\end{array}$ \\
\hline
\end{tabular}

resilience and green paradigm

Limited number of supply chain links and attributes were used reflecting on the literature review which gives a fractional view on supply chain dynamics

attributes (Carvalho and

Cruz-Machado, 2011)

Structural model (Yang et $\quad$ Validated Multisectoral Used of structural model and al., 2011)

\begin{tabular}{llll}
\hline $\begin{array}{l}\text { Lean Product and Process } \\
\text { Development Model (Sorli et } \\
\text { al., 2012) }\end{array}$ & Validated & Multisectoral & $\begin{array}{l}\text { Use life cycle of a product to create } \\
\text { value incorporated with } \\
\text { sustainability and cost effectiveness }\end{array}$ \\
\hline $\begin{array}{l}\text { SIRIM Green 5-S Model } \\
\text { for Sustainable }\end{array}$ & Conceptual & General & $\begin{array}{l}\text { Aimed to reduce waste, improve } \\
\text { process and obtain economic savings }\end{array}$ \\
\hline
\end{tabular}

Development/Integrated

Lean Management System

Model (Ho, 2012)

\begin{tabular}{|c|c|c|c|}
\hline $\begin{array}{l}\text { Integrated Lean, Agile, } \\
\text { Resilient and Green } \\
\text { (LARG) analytic network } \\
\text { process (ANP) model to }\end{array}$ & Validated & $\begin{array}{l}\text { Auto-maker } \\
\text { supply chain }\end{array}$ & $\begin{array}{l}\text { Aided the process of selecting } \\
\text { appropriate practices and key } \\
\text { performance indicators to establish } \\
\text { in firms in the supply chain industry }\end{array}$ \\
\hline
\end{tabular}
contextual analysis to show the impact of lean manufacturing on environmental performance

process (ANP) model to

in firms in the supply chain industry

Limited applications and

generalizability to other industries

other than automaker supply chain lacked the applicability for in depth case studies especially addressing aspects such as laws, regulations and carbon management.

Limited effectiveness of tools and techniques to harness the targeted outcomes according to the field study Limited applicability and validity to global sustainability and competitiveness

(Cecision-making

(Cabral et al., 2012) 


\begin{tabular}{lll}
\hline $\begin{array}{l}\text { Proposed model } \\
\text { (authors, year) }\end{array}$ & $\begin{array}{l}\text { Model type } \\
*\end{array}$ & Context \\
\hline $\begin{array}{l}\text { Model which indicates the } \\
\text { relationship between Green }\end{array}$ & Conceptual & Automotive \\
$\begin{array}{l}\text { Lean Six Sigma (GLSS) } \\
\text { and Financial Performance } \\
\text { (FP) (Zamri et al., 2013) }\end{array}$ & & \\
\hline $\begin{array}{l}\text { Conceptual framework } \\
\text { (Jabbour et al, 2013) }\end{array}$ & Validated & Automotive \\
\hline
\end{tabular}

Strengths

Limitation

Used of structural equation modelling to demonstrate the relationships between Green Lean Six

Sigma and Financial Performance Provided statistical validation for relationships between environmental management, operational performance management and human resources, lean manufacturing and environmental management

The model of efficient and $\quad$ Validated Forming tube
sustainable improvements
in a lean production system
(Aguado et al., 2013)

Aided to align efficiency and sustainability through innovation and helps to quantify the improvements representing environmental sustainability as a results of minimised usage of raw materials and thereby reduced environmental impact

An approach for
incorporating both lean
and green strategies into a
manufacturing system

Validated Automotive

Used of discrete event simulation model to integrate lean and green strategies

(Diaz-Elsayed et al., 2013)

\begin{tabular}{llll}
\hline $\begin{array}{l}\text { A model of waste } \\
\text { management combing lean } \\
\text { and green (Fercoq et al., } \\
\text { 2013) }\end{array}$ & Conceptual & General & $\begin{array}{l}\text { Focus on constant minimisation of } \\
\text { waste }\end{array}$ \\
\hline $\begin{array}{l}\text { Lean-ecosphere' } \\
\text { management system- using } \\
\text { interpretive structural } \\
\text { modeling and analytical } \\
\text { network process (Wong } \\
\text { and Wong, 2014) }\end{array}$ & Validated & Semiconductor & $\begin{array}{l}\text { Established a solid foundation on } \\
\text { lean management through a } \\
\text { scientific methodology while } \\
\text { incorporating the human aspects }\end{array}$ \\
\hline $\begin{array}{l}\text { Lean \& Green Model } \\
\text { (Pampanelli et al., 2014) }\end{array}$ & Validated & Automotive & $\begin{array}{l}\text { Provided a detailed analysis for the } \\
\text { manufacturing plant cell }\end{array}$ \\
\hline
\end{tabular}

\begin{tabular}{lll}
\hline Interpretive structural & Conceptual & Automotive \\
model (Govindan et al., & & supply chain \\
2015) & &
\end{tabular}

Identified inter-links among lean, green and supply chain management to categorise their "driving or dependence power".

A supply chain planning $\quad$ Validated
model (Fahimnia et al.,
2015)

Assessed the trade-offs among cost and deterioration of the environment by means of carbon gas emissions, energy usage and waste production by use of complex mathematical modelling approach

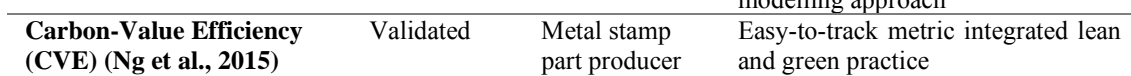
part producer

Used a stage-based theoretical model A stage-based theoretical Validated Multisectoral Used a stage-based theoretical model
to demonstrate mutuality of leansustainability and to holistic change in the process. This could be used a benchmark tool to evaluate performance of an organization.

\begin{tabular}{|c|c|c|c|c|}
\hline $\begin{array}{l}\text { Integrated sustainable } \\
\text { practices model } \\
\text { incorporating the most } \\
\text { popular lean, green, and } \\
\text { social practices (Wu et al., } \\
\text { 2015) }\end{array}$ & Validated & $\begin{array}{l}\text { Automobile } \\
\text { (auto-fashion) }\end{array}$ & $\begin{array}{l}\text { Demonstrated the integration of lean, } \\
\text { green and social practices and its } \\
\text { effects on the triple bottom line } \\
\text { cumulatively than by individually } \\
\text { implementing the activities }\end{array}$ & $\begin{array}{l}\text { Limited generalizability to other } \\
\text { sectors other than the an auto fashion } \\
\text { industry }\end{array}$ \\
\hline $\begin{array}{l}\text { Integrated lean and } \\
\text { green assessment of } \\
\text { production systems } \\
\text { (Greinacher et al., 2015) }\end{array}$ & Validated & Metal & $\begin{array}{l}\text { Used discrete event simulation tool } \\
\text { for monetary assessment of lean } \\
\text { and green manufacturing systems } \\
\text { considering energy and material } \\
\text { usage }\end{array}$ & $\begin{array}{l}\text { Limited capacity to identify the } \\
\text { identify the best combination of both } \\
\text { lean and green strategies in } \\
\text { manufacturing systems }\end{array}$ \\
\hline
\end{tabular}

* 1. Conceptual model = composition of concepts, which are used to help people know, understand, or simulate a subject; 2. Validated model= developed model being validated for a particular application/case study or tested with empirical evidence from industry 
Of the validated models, Aguado et al. (2013) proposed a model to harmonise efficiency and sustainable improvement in a lean production system based on environmental innovation. The pull methodology and extended value stream mapping were instrumental in implementing this model. Limited availability of databases to acquire information is however a constraint in the application of this model. This model can be further improved by amalgamating sustainable business archetypes suggested by Bocken et al. (2014). These archetypes maximise material and energy efficiency, create value from waste, and substitute with renewable and natural processes under technological innovation.

A lean and green model was developed for a manufacturing process at a cell level to decrease waste during production and minimise negative effects on the environment (Pampanelli et al., 2014). This model was constrained through a cell level in a manufacturing context. Since this model is applied at a cell level, its application at a plant level manufacturing process could be incorporated, and even expanded for upstream and downstream supply chains. $\mathrm{Ng}$ et al. (2015) proposed a carbon-value efficiency (CVE) which could be used as a standardization tool to assess the amount of value added time produced per unit of carbon footprint. This was an easy-to-track metric integrated lean and green practice and was consistent with previous work of Brown et al. (2014), Faulkner and Badurdeen (2014), Kurdve et al. (2014) and Marimin et al. (2014). There is limited generalizability in this application as it was specific to a metal stamp production context. Carbon-value efficiency could be further improved by being integrated with sustainability approaches such as zero emission initiatives and low carbon manufacturing solutions, and then applying to case studies from different industries.

Lean and sustainability were further modelled through a structural model and contextual analysis by Yang et al. (2011) who showed lean manufacturing as a vital precursor of environmental sustainability practice as lean transcends green. Piercy and Rich (2015) proposed a stage-based theoretical model demonstrating mutuality of lean-sustainability which could be used as a benchmark tool to evaluate performance of an organization. Future research on developing scales and calibration tools for multiple dimensions of environmental sustainability will be instrumental in applications in different industries. The compatibility of life cycle assessment with the lean and green model would be a prospective future research area. Carvalho et al. (2011a) conceptualised a model to identify the synergistic effects, divergences caused by lean, agile, resilience and green paradigm which was limited to principle paths between KPIs (key performance indicators) and supply chain features. This conceptual model highlighted the necessity of agility which is a critical ability for many organizations to 
quickly adapt and thrive in a changing business environment creating opportunistic pathways for the integration of lean and green principles (Carvalho et al., 2011b). Wu, et al. (2015) suggested an integrated sustainable practice model which considered the prevalent lean green and social practices, proposing a framework where the integration of practices will affect the triple bottom line cumulatively than by individually implementing the activities. This integrated sustainable practice model was validated using a case study in an auto fashion industry in China, hence providing limited generalizability. A larger sample of multiple case studies could be used to further validate this model. This model could also improve the social practice aspect of sustaianability by using concepts such as "consumer care", since there is an increasing trend to be conscious of consumer wellbeing.

In discussing the role of supply chain Duarte et al. (2011) proposed a conceptual model combining a lean and green supply chain into a performance measurement system, utilising the balanced scorecard method. Hajmohammad et al. (2013a) also posited a model showing supply management and lean practices are positively influencing environmental performance. Integrating the concept of "sustainable sourcing" for the lean supply chain management could pave the way for better performance in lean and green supply chain management.

Of these validated models some researchers used mathematical modelling, simulation and optimisation. For example Diaz-Elsayed et al. (2013) proposed an approach which required creating a discrete event simulation model. This model could be developed further by adding quantitative and qualitative environmental management factors within the industries such as lighting levels, air conditioning, compressed air (e.g.: actual heat load, air conditioner efficiency), electrical systems (e.g.: power factor, load scheduling) and boilers (e.g.: capacity) and identify quantifiable costs and benefits related to these green strategies. This method could be also used as an internal calibration tool for the organization to assess and benchmark environmental performance along with operational performance.

Sawhney et al. (2007) presented the En-Lean method to facilitate the developing association of lean practices and environmental considerations for a specific process by using HTML and JavaScript codes. Miller et al. (2010) proposed a model to investigate manufacturing process by using discrete event simulation and optimization to eliminate waste in manufacturing process. This model aid the selection of suppliers with minimal transportation distance and thereby reducing carbon footprint in the supply chain. Optimisation principles were also used by Mashaei et al. (2011) to reduce energy usage in a cyclic pallet system. For this purpose, the mean value of the energy usage of the pallet system was modelled which was 
then used as the objective function of the optimization model. Constraints such as cyclic and dynamic behaviour, queueing policy, and buffer size were used when developing the model. The final solution provides the optimal values of the system control variables, namely, number of pallets and conveyor velocity which leads to significant energy savings.

Fahimnia et al. (2015) suggested a tactical supply chain planning model (complex mathematical model and solution approach) to assess the trade-offs among cost and deterioration of the environment by means of carbon gas emissions, energy usage and waste production. Wider application of these models could be provided if they were tested in different industries, considering similarity in environmental impacts. However, mathematical modelling, simulation and optimisation, requires data and the complex nature of the model may be challenging for certain organizational contexts. Factors of the volatile external environment such as government regulations, policies and competitions by other companies in the industry can be incorporated to improve these models.

A lean-green transformation model was proposed to establish a lean and green organisational culture based on existing management business models included in awards, standards and frameworks. The criticality of employee engagement, leadership, strategic planning was highlighted in deploying lean and green in a systematic manner (Duarte and CruzMachado, 2013b). Lean practices could be aligned with sustainability to use material, energy and water efficiently (e.g.: green manufacturing) and to shift from conventional processes to renewable energy options and regenerative designs. For this purpose lean and green frameworks can be integrated with environmental management practices such as environmental management systems, environmental policy, environmental auditing, life cycle analysis, green manufacturing, zero emission initiatives and biomimicry. Such constructs provide a good breeding ground for future research which could be beneficial for both the academics as well as and industrial practitioners. While lean thinking is evolving in manufacturing sector rectifying errors in processes, future research could explore how lean value systems could be developed in a "green-field" environment (Hines et al., 2004).

Toyota has successfully demonstrated lean and green process management, with their manufacturing excellence in lean manufacturing and commitment to social and environmental sustainability. Toyota believed in the synergy between nature and value adding to society (Zokaei et al., 2013). Wal-Mart has also been successful in using lean and green concepts where they reduced the height of building structures in stores and the space in facilities which leads to reduction in energy consumption (Fliedner, 2008). 
However, organizations will face barriers and challenges in applying lean and green principles to their organizational context. A lack of technical knowledge (Alinaitwe, 2009), lack of support from top management (Kim and Park, 2006), resistance to change because of the novelty of the concept (Wycherley, 1999), risk aversive nature (Adriana Rossiter et al., 2011), attitude of humans (Howell, 1999) financial costs incurred in re-designing of processes and provisions for contingency plans (Oladiran, 2008) are some of the identified barriers in implementing lean and green initiatives. This means many manufacturers initially pick on the low hanging fruit (e.g.: changing light bulbs) and gradually move towards major transformation in the manufacturing processes, thereby strengthening capabilities and resources to improve the benefits in lean and green practices.

\section{Conclusion}

This paper synthesizes the state-of-art research on the relationship between lean thinking and sustainable business practice. The purpose of this review was twofold; to establish the range of lean and green methods that are readily available for industrial practitioners, and to distinguish a number of existing lean and green models that can be used to embed lean thinking in sustainable business processes. As the lean and green models reviewed were mostly applied to a specific industry or context with few generalizable models, the authors also considered opportunities for models to be used in other, broader contexts. An emergent quadrant framework was developed to synthesize the literature on lean and green thinking, which could also be used as a guide to further investigate how lean thinking can be adopted as a targeted approach to construct sustainable business models that reduce waste and improve material efficiency, and minimise costs in business processes.

Sustainable business practice is supported by numerous and evolving approaches spanning environmental management systems, policies, auditing, reporting, legal litigation and risk assessment, life cycle assessment, and the triple bottom line. Lean thinking is another emerging approach, with significant potential - through the 'lean and green' philosophy - to transform an organization's performance with well-integrated and aligned sustainable business practices. Lean and green models can harness the best outcomes for business, integrating sustainable concepts such as resource productivity and cleaner production to concurrently reduce waste and improve material efficiency.

It is clear that from a resource efficiency perspective, lean thinking is a critical, but still underutilised approach within the modern industrial system. This review presented specific lean methods which could be better utilised to reduce specific environmental impact and 
models integrating the lean and green concept. The review evaluated a number of lean and lean integrated methods, from which the authors conclude that there is minimal application of lean methods beyond waste and energy, to support areas such as chemical and water management.

The literature review also established a knowledge gap of an extensive system in finding targeted solutions for different types of environmental impacts (e.g.: solid waste, greenhouse gas emissions, waste water) and appropriate lean methods or models aimed at each context. Most research has focused on exploring specific lean methods and models only providing solutions for a specific environmental impact, for example: reducing volatile organic compounds (Rothenberg et al., 2001), efficient energy use (Ball, 2015), reducing carbon footprint ( $\mathrm{Ng}$ et al., 2015), and waste management (Kurdve et al., 2015; Maxwell et al., 1998). The authors propose that a more holistic approach could link specific lean methods and models to a larger scope of environmental issues with multiple benefits in integrated manufacturing excellence and improved uptake of sustainable business practice from the same initiative.

Future research could develop a holistic system to explore pathways for lean principles to be augmented with sustainability concepts such as low carbon manufacturing, green chemistry, biomimicry and regenerative design. It is anticipated that the synergistic effect of such a lean and green paradigm would improve economic and environmental outcomes in an organization.

Looking ahead, there are a number of implications of this research for industry and within academia. How this integration of lean and green paradigm should be executed as a pathway for corporate sustainable development demands deeper exploration. Structuring, categorising and finding relationships between sustainable work streams and lean practices can stimulate research on the simultaneous implementation of lean and sustainable business practices and their compatibility. For example, academics and practitioners could further study lean methods to better manage the use of chemicals and water in manufacturing processes.

Industrial practitioners can identify opportunities in lean thinking not only towards excellence in manufacturing but also to fulfil their responsibility towards the environment in a collective effort. The lean and green matrix, conceptual and numerical lean green models presented in this paper will benefit both researchers and industrialists in gaining valuable information on the influence of lean practices in increasing corporate environmental sustainability, and thereby provide new paradigms and pathways to achieve a balance in environmental and economic priorities in sustainable business practice. 


\section{Acknowledgements}

The authors of this study kindly acknowledge the financial support given by QUT Postgraduate Research Award (QUTPRA) which is rewarded by the Queensland University of Technology, Brisbane, Australia. I acknowledge the support of the QUT Academic Language and Learning Service, in particular Karyn Gonano in the writing and development of this article.

\section{References}

Adriana Rossiter, H., Hofer, C., Eroglu, C., Waller, M.A., 2011. An institutional theoretic perspective on forces driving adoption of lean production globally. International Journal of Logistics Management 22, 148-178. Aguado, S., Alvarez, R., Domingo, R., 2013. Model of efficient and sustainable improvements in a lean production system through processes of environmental innovation. Journal of Cleaner Production 47, 141-148. Alinaitwe, H.M., 2009. Prioritising lean construction barriers in Uganda's construction industry. Journal of Construction in Developing Countries 14, 15-30.

Amani, P., Lindbom, I., Sundström, B., Östergren, K., 2015. Green-Lean Synergy-Root-Cause Analysis in Food Waste Prevention. International Journal on Food System Dynamics 6, 99-109.

Azevedo, S.G., Carvalho, H., Duarte, S., Cruz-Machado, V., 2012. Influence of green and lean upstream supply chain management practices on business sustainability. Engineering Management, IEEE Transactions on 59, 753-765.

Ball, P., 2015. Low energy production impact on lean flow. Journal of Manufacturing Technology Management 26, 412.

Banawi, A., Bilec, M.M., 2014. A framework to improve construction processes: Integrating Lean, Green and Six Sigma. International Journal of Construction Management 14, 45-55.

Bandehnezhad, M., Zailani, S., Fernando, Y., 2012. An empirical study on the contribution of lean practices to environmental performance of the manufacturing firms in northern region of Malaysia. International Journal of Value Chain Management 6, 144-168.

Barnett-Page, E., Thomas, J., 2009. Methods for the synthesis of qualitative research: a critical review. BMC medical research methodology 9,1 .

Bashkite, V., Karaulova, T., 2012. Integration of Green thinking into Lean fundamentals by Theory of Inventive Problems-Solving tools. DAAAM International, Vienna, Austria, EU, 345-350.

Bazeley, P., Jackson, K., 2013. Qualitative data analysis with NVivo. Sage Publications Limited.

Bergmiller, G.G., McCright, P.R., 2009. Parallel models for lean and green operations, Proceedings of the 2009 Industrial Engineering Research Conference, Miami, FL.

Bergmiller, G.G.P., McCright, P.R.P., 2011. Achieving Total Sustainability by Cleaning Up the Dirty Dozen. IIE Annual Conference. Proceedings, 1-8.

Besseris, G.J., Kremmydas, A.T., 2014. Concurrent multi-response optimization of austenitic stainless steel surface roughness driven by embedded lean and green indicators. Journal of Cleaner Production 85, 293-305. Bhamu, J., Singh Sangwan, K., 2014. Lean manufacturing: literature review and research issues. International Journal of Operations \& Production Management 34, 876.

Bocken, N.M.P., Short, S.W., Rana, P., Evans, S., 2014. A literature and practice review to develop sustainable business model archetypes. Journal of Cleaner Production 65, 42-56.

Boons, F., Lüdeke-Freund, F., 2013. Business models for sustainable innovation: state-of-the-art and steps towards a research agenda. Journal of Cleaner Production 45, 9-19.

Briner, R.B., Denyer, D., 2012. Systematic review and evidence synthesis as a practice and scholarship tool. Handbook of evidence-based management: Companies, classrooms and research, 112-129.

Brown, A., Amundson, J., Badurdeen, F., 2014. Sustainable value stream mapping (Sus-VSM) in different manufacturing system configurations: application case studies. Journal of Cleaner Production 85, 164-179. Byers, W., Lindgren, G., Noling, C., Peters, D., 2010. Water Reclamation Strategies and Technologies, Industrial Water Management. John Wiley \& Sons, Inc., pp. 3-1-3-27.

Cabral, I., Grilo, A., Cruz-Machado, V., 2012. A decision-making model for Lean, Agile, Resilient and Green supply chain management. International Journal of Production Research 50, 4830.

Carvalho, H., Cruz-Machado, V., 2011. Integrating Lean, Agile, Resilience and Green Paradigms in Supply Chain Management (LARG_SCM). INTECH Open Access Publisher.

Carvalho, H., Duarte, S., Cruz Machado, V., 2011a. Lean, agile, resilient and green: divergencies and synergies. International Journal of Lean Six Sigma 2, 151-179.

Carvalho, H., Duarte, S., Machado, V.C., 2011b. Lean, agile, resilient and green: divergencies and synergies. International Journal of Lean Six Sigma 2, 151-179. 
Ceulemans, K., Molderez, I., Van Liedekerke, L., 2015. Sustainability reporting in higher education: a comprehensive review of the recent literature and paths for further research. Journal of Cleaner Production 106, 127-143.

Chahal, V., 2012. An Advance Lean Production System In Industry To Improve Flexibility And Quality In manufacturing By Implementation Of FMS \& Green Manufacturing. International Journal of Emerging Technology and Advanced Engineering, Certified Journal 2.

Chaplin, L., Simon, T.J.O.R., 2014. Lean Six Sigma and marketing: a missed opportunity. International Journal of Productivity and Performance Management 63, 665-674.

Chiarini, A., 2014. Sustainable manufacturing-greening processes using specific Lean Production tools: an empirical observation from European motorcycle component manufacturers. Journal of Cleaner Production 85, 226-233

Corbett, C.J., Klassen, R.D., 2006. Extending the Horizons: Environmental Excellence as Key to Improving Operations. Manufacturing \& Service Operations Management 8, 5-22.

Cosimato, S., Troisi, O., 2015. Green supply chain management. TQM Journal 27, 256-276.

D'Errico, F., Perricone, G., Oppio, R., 2009. A New Integrated Lean Manufacturing Model for Magnesium Products. JOM 61, 14-18.

Darnall, N., Gallagher, D.R., Andrews, R.N., Amaral, D., 2000. Environmental management systems: Opportunities for improved environmental and business strategy. Environmental Quality Management 9, 1-9. Denyer, D., Tranfield, D., 2009a. Producing a systematic review.

Denyer, D., Tranfield, D., 2009b. Producing a systematic review, in: Bryman, D.A.B.A. (Ed.), The Sage handbook of organizational research methods. Sage Publications Ltd, Thousand Oaks, CA, pp. 671-689. Dhingra, R., Kress, R., Upreti, G., 2014. Does lean mean green? Journal of Cleaner Production 85, 1-7. Diaz-Elsayed, N., Jondral, A., Greinacher, S., Dornfeld, D., Lanza, G., 2013. Assessment of lean and green strategies by simulation of manufacturing systems in discrete production environments. CIRP Annals Manufacturing Technology 62, 475-478.

Duarte, S., Cabrita, R., Machado, V.C., 2011. Exploring lean and green supply chain performance using balanced scorecard perspective, Proceedings of the 2011 International Conference on Industrial Engineering and Operations Management, pp. 520-525.

Duarte, S., Cruz-Machado, V., 2013a. Lean and green: a business model framework, Proceedings of the Sixth International Conference on Management Science and Engineering Management. Springer, pp. 751-759.

Duarte, S., Cruz-Machado, V., 2013b. Modelling lean and green: a review from business models. International Journal of Lean Six Sigma 4, 228-250.

Duarte, S., Cruz-Machado, V., 2014a. Investigating lean and green supply chain linkages through a balanced scorecard framework. International Journal of Management Science and Engineering Management 10, 20-29. Duarte, S., Cruz-Machado, V.A., 2014b. Lean and Green Supply Chain Performance: A Balanced Scorecard Perspective, Proceedings of the Eighth International Conference on Management Science and Engineering Management. Springer, pp. 645-654.

Dubey, R., Ali, S.S., 2015. Exploring antecedents of extended supply chain performance measures.

Benchmarking 22, 752-772.

Dües, C.M., Tan, K.H., Lim, M., 2013. Green as the new Lean: how to use Lean practices as a catalyst to greening your supply chain. Journal of Cleaner Production 40, 93-100.

Easterby-Smith, M., Thorpe, R., Jackson, P.R., 2012. Management research. Sage.

Ekins, P., 1999. European environmental taxes and charges: recent experience, issues and trends. Ecological economics 31, 39-62.

Esfandyari, A., Härter, S., Javied, T., Franke, J., 2015. A Lean Based Overview on Sustainability of Printed Circuit Board Production Assembly. Procedia CIRP 26, 305-310.

Esmemr, S., Ceti, I.B., Tuna, O., 2010. A Simulation for Optimum Terminal Truck Number in a Turkish Port Based on Lean and Green Concept. The Asian Journal of Shipping and Logistics 26, 277-296.

Espadinha-Cruz, P., Grilo, A., Puga-Leal, R., Cruz-Machado, V., 2011. A model for evaluating Lean, Agile, Resilient and Green practices interoperability in supply chains, Industrial Engineering and Engineering Management (IEEM), 2011 IEEE International Conference on. IEEE, pp. 1209-1213.

Fahimnia, B., Sarkis, J., Eshragh, A., 2015. A tradeoff model for green supply chain planning:A leannessversus-greenness analysis. Omega 54, 173-190.

Faulkner, W., Badurdeen, F., 2014. Sustainable Value Stream Mapping (Sus-VSM): methodology to visualize and assess manufacturing sustainability performance. Journal of Cleaner Production 85, 8-18.

Fercoq, A., Lamouri, S., Carbone, V., Lelièvre, A., Lemieux, A.A., 2013. Combining lean and green in manufacturing: a model of waste management. IFAC Proceedings Volumes 46, 117-122.

Fliedner, G., 2008. Sustainability: a new lean principle, Proceedings of the 39th annual meeting of the decision sciences institute, Baltimore, Maryland, pp. 3321-3326.

Fliedner, G., Majeske, K., 2010. Sustainability: the new lean frontier. Production and Inventory Management Journal 46, 6-13. 
Florida, R., 1996. Lean and green: The move to environmentally conscious manufacturing. California Management Review 39, 80-105.

Folinas, D., Aidonis, D., Malindretos, G., Voulgarakis, N., Triantafillou, D., 2014. Greening the agrifood supply chain with lean thinking practices. International Journal of Agricultural Resources, Governance and Ecology 6 10, 129-145.

Folinas, D., Aidonis, D., Triantafillou, D., Malindretos, G., 2013. Exploring the Greening of the Food Supply Chain with Lean Thinking Techniques. Procedia Technology 8, 416-424.

Galeazzo, A., Furlan, A., Vinelli, A., 2014. Lean and green in action: interdependencies and performance of pollution prevention projects. Journal of Cleaner Production 85, 191-200.

Garetti, M., Taisch, M., 2012. Sustainable manufacturing: trends and research challenges. Production Planning \& Control 23, 83-104.

Garza-Reyes, J.A., 2015. Lean and green - a systematic review of the state of the art literature. Journal of Cleaner Production 102, 18-29.

González-Benito, J., González-Benito, Ó., 2008. Operations management practices linked to the adoption of ISO 14001: An empirical analysis of Spanish manufacturers. International Journal of Production Economics 113, 60-73.

Govindan, K., Azevedo, S.G., Carvalho, H., Cruz-Machado, V., 2015. Lean, green and resilient practices influence on supply chain performance: interpretive structural modeling approach. International Journal of Environmental Science and Technology 12, 15-34.

Govindan, K., Kannan, D., Shankar, M., 2014. Evaluation of green manufacturing practices using a hybrid MCDM model combining DANP with PROMETHEE. International Journal of Production Research, 1-28. Greinacher, S., Moser, E., Hermann, H., Lanza, G., 2015. Simulation Based Assessment of Lean and Green Strategies in Manufacturing Systems. Procedia CIRP 29, 86-91.

Hajmohammad, S., Vachon, S., Klassen, R.D., Gavronski, I., 2013a. Lean management and supply management: their role in green practices and performance. Journal of Cleaner Production 39, 312-320. Hajmohammad, S., Vachon, S., Klassen, R.D., Gavronski, I., 2013b. Lean management and supply management: their role in green practices and performance. Journal of Cleaner Production 56, 86-93. Hartini, S., Ciptomulyono, U., 2015. The Relationship between Lean and Sustainable Manufacturing on Performance: Literature Review. Procedia Manufacturing 4, 38-45.

Herron, C., Hicks, C., 2008. The transfer of selected lean manufacturing techniques from Japanese automotive manufacturing into general manufacturing (UK) through change agents. Robotics and Computer-Integrated Manufacturing 24, 524-531.

Hillary, R., 2000. Small and medium-sized enterprises and the environment: business imperatives. Greenleaf Publishing.

Hines, P., Holweg, M., Rich, N., 2004. Learning to evolve: A review of contemporary lean thinking. International Journal of Operations \& Production Management 24, 994-1011.

Hines, P., Rich, N., 1997. The seven value stream mapping tools. International journal of operations \& production management 17, 46-64.

Ho, S., Mohd Hashim, A.G.B., Mohd Idris, M.A., 2015. Applicability of SIRIM Green 5-S Model for productivity \& business growth in Malaysia. TQM Journal 27, 185-196.

Ho, S.K., 2012. Global Sustainable Development through the Integrated Lean Management (Green 5-S) Model for TQM. Nang Yan Business Journal 1, 27-37.

Hong, P., Ga Yang, M., D. Dobrzykowski, D., 2014. Strategic customer service orientation, lean manufacturing practices and performance outcomes. Journal of Service Management 25, 699.

Hong, P., James Jungbae, R., Rawski, G., 2012. Benchmarking sustainability practices: evidence from manufacturing firms. Benchmarking 19, 634-648.

Howell, G.A., 1999. What is lean construction-1999, Proceedings IGLC. Citeseer, p. 1.

IEA, 2007. Tracking industrial energy efficiency and CO2 emissions: in support of the G8 plan of action : energy indicators. International Energy Agency, FR.

Jabbour, C.J.C., Jabbour, A.B.L.d.S., Govindan, K., Teixeira, A.A., Freitas, W.R.d.S., 2013. Environmental management and operational performance in automotive companies in Brazil: the role of human resource management and lean manufacturing. Journal of Cleaner Production 47, 129-140.

Jasti, N.V.K., Sharma, A., Kodali, R., 2012. Lean to green supply chain management: a case study. Journal of Environmental Research and Development 6.

Johansson, G., Sundin, E., 2014. Lean and green product development: two sides of the same coin? Journal of Cleaner Production 85, 104-121.

Kim, D., Park, H.-S., 2006. Innovative construction management method: Assessment of lean construction implementation. KSCE journal of Civil Engineering 10, 381-388.

King, A.A., Lenox, M.J., 2001. Lean and green? An empirical examination of the relationship between lean production and environmental performance. Production and Operations Management 10, 244-256. 
Kitchenham, B., Pearl Brereton, O., Budgen, D., Turner, M., Bailey, J., Linkman, S., 2009. Systematic literature reviews in software engineering - A systematic literature review. Information and Software Technology 51, 715 .

Kleindorfer, P.R., Singhal, K., Van Wassenhove, L.N., 2005. Sustainable Operations Management. Production and Operations Management 14, 482-492.

Klotz, L., Horman, M., Bodenschatz, M., 2007. A lean modeling protocol for evaluating green project delivery. Lean Construction Journal 3, 1-18.

Kurdve, M., Shahbazi, S., Wendin, M., Bengtsson, C., Wiktorsson, M., 2015. Waste flow mapping to improve sustainability of waste management: a case study approach. Journal of Cleaner Production 98, 304-315.

Kurdve, M., Zackrisson, M., Wiktorsson, M., Harlin, U., 2014. Lean and green integration into production system models - experiences from Swedish industry. Journal of Cleaner Production 85, 180-190.

Larson, T., Greenwood, R., 2004. Perfect complements: Synergies between lean production and ecosustainability initiatives. Environmental Quality Management 13, 27-36.

Lenssen, M.P., Aileen Ionescu-Somers, Simon Pickard, G., Bocken, N., Short, S., Rana, P., Evans, S., 2013. A value mapping tool for sustainable business modelling. Corporate Governance 13, 482-497.

Leonard, P., 2013. Changing Organizational Space: Green? Or Lean and Mean? Sociology 47, 333-349.

Levy, Y., Ellis, T.J., 2006. A systems approach to conduct an effective literature review in support of information systems research. Informing Science: International Journal of an Emerging Transdiscipline 9, 181212.

Lüdeke-Freund, F., 2010. Towards a Conceptual Framework of'Business Models for Sustainability'. Knowledge collaboration \& learning for sustainable innovation, R. Wever, J. Quist, A. Tukker, J. Woudstra, F. Boons, N. Beute, eds., Delft.

Maleki, M., Machado, V.C., 2013. Generic Integration of Lean, Agile, Resilient, and Green Practices in Automotive Supply Chain. Revista de Management Comparat International 14, 237-248.

Marhani, M.A., Jaapar, A., Bari, N.A.A., 2012. Lean Construction: Towards Enhancing Sustainable Construction in Malaysia. Procedia - Social and Behavioral Sciences 68, 87-98.

Marhani, M.A., Jaapar, A., Bari, N.A.A., Zawawi, M., 2013. Sustainability Through Lean Construction Approach: A Literature Review. Procedia - Social and Behavioral Sciences 101, 90-99.

Marimin, Darmawan, M.A., Machfud, Islam Fajar Putra, M.P., Wiguna, B., 2014. Value chain analysis for green productivity improvement in the natural rubber supply chain: a case study. Journal of Cleaner Production 85, 201-211.

Martínez-Jurado, P.J., Moyano-Fuentes, J., 2014. Lean Management, Supply Chain Management and Sustainability: A Literature Review. Journal of Cleaner Production 85, 134-150.

Mashaei, M., Lennartson, B., Abbestam, G., 2011. Green and lean control of cyclic pallet systems, Automation Science and Engineering (CASE), 2011 IEEE Conference on. IEEE, pp. 642-647.

Maxwell, J., Briscoe, F., Schenk, B., Rothenberg, S., 1998. Case study: Honda of America Manufacturing, Inc.: Can lean production practices increase environmental performance? Environmental Quality Management 8, 53 61.

Miller, G., Pawloski, J., Standridge, C.R., 2010. A case study of lean, sustainable manufacturing. Journal of industrial engineering and management 3, 11-32.

Mollenkopf, D., Stolze, H., Tate, W.L., Ueltschy, M., 2010. Green, lean, and global supply chains. International Journal of Physical Distribution \& Logistics Management 40, 14-41.

Moscardo, G., 2013. Sustainability in Australian business: principles and practice. John Wiley and Sons Australia, Milton, Qld.

Moser, T., 2001. MNCs and Sustainable Business Practice: The Case of the Colombian and Peruvian Petroleum Industries. World Development 29, 291-309.

Ng, R., Low, J.S.C., Song, B., 2015. Integrating and implementing Lean and Green practices based on proposition of Carbon-Value Efficiency metric. Journal of Cleaner Production 95, 242-255.

Ogunbiyi, O., Adebayo, O., Goulding, J., 2014. An empirical study of the impact of lean construction techniques on sustainable construction in the UK. Construction Innovation 14, 88-107.

Oladiran, O.J., 2008. Lean-in-Nigerian construction: State, barriers, strategies and 'Go-To-Gemba'approach'. Proceedings of the IGLC-16, Manchester, UK, 16-18.

Ōno, T., 1988. Toyota production system: beyond large-scale production. Productivity press.

Pampanelli, A.B., Found, P., Bernardes, A.M., 2014. A Lean \&amp; Green Model for a production cell. Journal of Cleaner Production 85, 19-30.

Piercy, N., Rich, N., 2015. The relationship between lean operations and sustainable operations. International Journal of Operations \& Production Management 35, 282.

Puvanasvaran, A., Kerk, R.S., Muhamad, M., 2011. Principles and business improvement initiatives of lean relates to Environmental Management System, Technology Management Conference (ITMC), 2011 IEEE International. IEEE, pp. 439-444. 
Ranky, P.G., Kalaba, O., Zheng, Y., 2012. Sustainable lean six-sigma green engineering system design educational challenges and interactive multimedia solutions, Sustainable Systems and Technology (ISSST), 2012 IEEE International Symposium on. IEEE, pp. 1-6.

Rothenberg, S., Pil, F.K., Maxwell, J., 2001. Lean, green, and the quest for superior environmental performance. Production and Operations Management 10, 228-243.

Rother, M., Shook, J., 2003. Learning to see: value stream mapping to add value and eliminate muda. Lean Enterprise Institute.

Salleh, N.A.M., Kasolang, S., Jaffar, A., 2012. Green Lean Total Quality Information Management in Malaysian Automotive Companies. Procedia Engineering 41, 1708-1713.

Sarah, E.A.D., Clifford, A., 2007. Ecopreneurship - a new approach to managing the triple bottom line. Journal of Organizational Change Management 20, 326-345.

Saunders, M., Lewis, P., Thornhill, A., 2012. Research methods for business students. Pearson, New York; Harlow, England.

Savin-Baden, M., Major, C.H., 2013. Qualitative research: the essential guide to theory and practice. Routledge, Milton Park, Abingdon, Oxon.

Sawhney, R., Teparakul, P., Bagchi, A., Li, X., 2007. En-Lean: a framework to align lean and green manufacturing in the metal cutting supply chain. International Journal of Enterprise Network Management 1, 238-260.

Schaper, M., 2002. The challenge of environmental responsibility and sustainable development: Implications for SME and entrepreneurship academics. Radical changes in the world: Will SMEs soar or crash, 541-553.

Seay, S., Narsing, A., 2013. Transitioning to a lean paradigm: a model for sustainability in the leasing and rental industries. Academy of Strategic Management Journal 12, 113-124.

Seidel, S., Recker, J.C., Pimmer, C., vom Brocke, J., 2010. Enablers and barriers to the organizational adoption of sustainable business practices, Proceeding of the 16th Americas conference on information systems: sustainable IT collaboration around the globe. Association for Information Systems.

Simons, D., Mason, R., 2003. Lean and green: doing more with less. ECR Journal 3, 84-91.

Simpson, D.F., Power, D.J., 2005. Use the supply relationship to develop lean and green suppliers. Supply Chain Management: An International Journal 10, 60-68.

Smith, M.H., Hargroves, K., Desha, C., 2010. Cents and sustainability: securing our common future by decoupling economic growth from environmental pressures. Earthscan, Washington, DC; London.

Sobral, M.C., Sousa Jabbour, A.B.L.d., Chiappetta Jabbour, C.J., 2013. Green Benefits From Adopting Lean Manufacturing: A Case Study From the Automotive Sector. Environmental Quality Management 22, 65-72. Soltero, C., Waldrip, G., 2002. Using Kaizen to Reduce Waste and Prevent Pollution. Environmental Quality Management 11, 23-38.

Song, L., Liang, D., 2011. Lean construction implementation and its implication on sustainability: a contractor's case study. Canadian Journal of Civil Engineering 38, 350-359.

Sorli, M., Sopelana, A., Salgado, M., Pelaez, G., Ares, E., 2012. Expanding lean thinking to the product and process design and development within the framework of sustainability. AIP Conference Proceedings 1431, $815-822$

Sorli, M., Sopelana, A., Taisch, M., Al-Shaab, A., Keast, J., Flores, M., Skotic, D., Martinez, L., 2010. Applying lean thinking concepts to new product development, APMS 2010 International Conference Advances in Production Management Systems Book of Abstracts. PoliScript, p. 50.

Stormer, F., 2003. Making the shift: Moving from" ethics pays" to an inter-systems model of business. Journal of Business Ethics 44, 279-289.

Stubbs, W., Cocklin, C., 2008. Conceptualizing a "sustainability business model”. Organization \& Environment 21, 103-127.

Taubitz, M.A., 2010. Lean, Green \& Safe. Professional Safety 55, 39-46.

Thomas, J., Harden, A., 2008. Methods for the thematic synthesis of qualitative research in systematic reviews. BMC medical research methodology $8,1$.

Tice, J., Ahouse, L., Larson, T., 2005. Lean production and EMSs: Aligning environmental management with business priorities. Environmental Quality Management 15, 1-12.

Vais, A., Miron, V., Pedersen, M., Folke, J., 2006. "Lean and Green" at a Romanian secondary tissue paper and board mill - Putting theory into practice. Resources, Conservation and Recycling 46, 44-74.

Venkat, K., Wakeland, W., 2006. Is lean necessarily green?, Proceedings of the 50th Annual Meeting of the ISSS-2006, Sonoma, CA, USA.

Verrier, B., Rose, B., Caillaud, E., Remita, H., 2014. Combining organizational performance with sustainable development issues: the Lean and Green project benchmarking repository. Journal of Cleaner Production 85, 8393.

Vinodh, S., Arvind, K.R., Somanaathan, M., 2011. Tools and techniques for enabling sustainability through lean initiatives. Clean Technologies and Environmental Policy 13, 469-479.

Webster, J., Watson, R.T., 2002. Analyzing the past to prepare for the future: Writing a literature review. Management Information Systems Quarterly 26, 3. 
White, G.R.T., James, P., 2014. Extension of process mapping to identify "green waste". Benchmarking 21, 835-850.

Wiengarten, F., Fynes, B., Onofrei, G., 2013. Exploring synergetic effects between investments in environmental and quality/lean practices in supply chains. Supply Chain Management 18, 148-160.

Williams, K.C., Page, R.A., Petrosky, A.R., 2014. Green Sustainability and New Social Media. Journal of Strategic Innovation and Sustainability 9, 11-33.

Womack, J.P., Jones, D.T., 1996. Lean thinking: Banish waste and create wealth in your organisation. Simon and Shuster, New York, NY 397.

Womack, J.P., Jones, D.T., 2010. Lean thinking: banish waste and create wealth in your corporation. Simon and Schuster.

Womack, J.P., Jones, D.T., Roos, D., 1990. Machine that changed the world. Simon and Schuster.

Wong, W.P., Wong, K.Y., 2014. Synergizing an ecosphere of lean for sustainable operations. Journal of Cleaner Production 85, 51-66.

Wu, L., Subramanian, N., Abdulrahman, M.D., Liu, C., Lai, K.H., Pawar, K.S., 2015. The Impact of Integrated Practices of Lean, Green, and Social Management Systems on Firm Sustainability Performance-Evidence from Chinese Fashion Auto-Parts Suppliers. Sustainability 7, 3838-3858.

Wu, P., Low, S.P., Jin, X., 2013. Identification of non-value adding (NVA) activities in precast concrete installation sites to achieve low-carbon installation. Resources, Conservation and Recycling 81, 60-70.

Wycherley, I., 1999. Greening supply chains: the case of the Body Shop International. Business Strategy and the Environment 8, 120.

Yang, M.G., Hong, P., Modi, S.B., 2011. Impact of lean manufacturing and environmental management on business performance: An empirical study of manufacturing firms. International Journal of Production Economics 129, 251-261.

Zamri, F.I.M., Hibadullah, S.N., Fuzi, N.M., Desa, A.F.N.C., Habidin, N.F., 2013. Green Lean Six Sigma and Financial Performance in Malaysian Automotive Industry. Business Management and Strategy 4, 97-106.

Zokaei, K., Lovins, H., Wood, A., Hines, P., 2013. Creating a Lean and Green Business System: Techniques for Improving Profits and Sustainability. CRC Press Inc, GB. 



\section{Appendix A}

\begin{tabular}{|c|c|c|c|c|c|}
\hline No & Author/s & Year & Title & $\begin{array}{l}\text { Journal / Conference } \\
\text { proceedings }\end{array}$ & Industrial area of application \\
\hline 1 & (Florida) & 1996 & $\begin{array}{l}\text { Lean and green: The move to environmentally conscious } \\
\text { manufacturing }\end{array}$ & $\begin{array}{l}\text { California Management } \\
\text { Review }\end{array}$ & Multisectoral \\
\hline 2 & (Maxwell et al.) & 1998 & $\begin{array}{l}\text { Case study: Honda of America Manufacturing, Inc.: Can lean } \\
\text { production practices increase environmental performance? }\end{array}$ & $\begin{array}{l}\text { Environmental Quality } \\
\text { Management }\end{array}$ & Automotive \\
\hline 3 & (King and Lenox) & 2001 & $\begin{array}{l}\text { Lean and green? An empirical examination of the relationship } \\
\text { between lean production and environmental performance }\end{array}$ & $\begin{array}{l}\text { Production and } \\
\text { Operations Management }\end{array}$ & Multisectoral \\
\hline 4 & (Rothenberg et al.) & 2001 & Lean, green, and the quest for superior environmental performance & $\begin{array}{l}\text { Production and } \\
\text { Operations Management }\end{array}$ & Automotive \\
\hline 5 & $\begin{array}{l}\text { (Soltero and } \\
\text { Waldrip) }\end{array}$ & 2002 & Using Kaizen to Reduce Waste and Prevent Pollution. & $\begin{array}{l}\text { Environmental Quality } \\
\text { Management }\end{array}$ & Theoretical \\
\hline 6 & (Simons and Mason) & 2003 & Lean and green: 'doing more with less' & ECR Journal & Theoretical \\
\hline 7 & $\begin{array}{l}\text { (Larson and } \\
\text { Greenwood) }\end{array}$ & 2004 & $\begin{array}{l}\text { Perfect Complements: Synergies between Lean Production and } \\
\text { Eco- Sustainability Initiatives }\end{array}$ & $\begin{array}{l}\text { Environmental Quality } \\
\text { Management }\end{array}$ & Theoretical \\
\hline 8 & (Hines et al.) & 2004 & Learning to evolve: A review of contemporary lean thinking & $\begin{array}{l}\text { International Journal of } \\
\text { Operations \& Production } \\
\text { Management }\end{array}$ & Theoretical \\
\hline 9 & (Simpson and Power) & 2005 & Use the supply relationship to develop lean and green suppliers. & $\begin{array}{l}\text { Supply Chain } \\
\text { Management }\end{array}$ & Automotive \\
\hline 10 & (Kleindorfer et al.) & 2005 & Sustainable operations management & $\begin{array}{l}\text { Production and } \\
\text { Operations Management }\end{array}$ & Theoretical \\
\hline 11 & (Tice et al.) & 2005 & $\begin{array}{l}\text { Lean Production and EMSs: Aligning Environmental Management } \\
\text { with Business Priorities }\end{array}$ & $\begin{array}{l}\text { Environmental Quality } \\
\text { Management }\end{array}$ & Theoretical \\
\hline 12 & $\begin{array}{l}\text { (Corbett and } \\
\text { Klassen) }\end{array}$ & 2006 & $\begin{array}{l}\text { Extending the Horizons: Environmental Excellence as Key to } \\
\text { Improving Operations }\end{array}$ & $\begin{array}{l}\text { Manufacturing \& Service } \\
\text { Operations Management }\end{array}$ & Theoretical \\
\hline 13 & $\begin{array}{l}\text { (Venkat and } \\
\text { Wakeland) }\end{array}$ & 2006 & Is lean necessarily green? & $\begin{array}{l}\text { Proceedings of the 50th } \\
\text { Annual Meeting of the } \\
\text { ISSS-2006 }\end{array}$ & Food supply chain \\
\hline 14 & (Vais et al.) & 2006 & $\begin{array}{l}\text { "Lean and Green" at a Romanian secondary tissue paper and board } \\
\text { mill—putting theory into practice }\end{array}$ & $\begin{array}{l}\text { Resources, Conservation } \\
\text { and Recycling }\end{array}$ & Paper and board mill \\
\hline 15 & (Klotz et al.) & 2007 & A lean modeling protocol for evaluating green project delivery. & $\begin{array}{l}\text { Lean Construction } \\
\text { Journal }\end{array}$ & Green building/Construction \\
\hline 16 & (Sawhney et al.) & 2007 & $\begin{array}{l}\text { En-Lean: a framework to align lean and green manufacturing in the } \\
\text { metal cutting supply chain }\end{array}$ & $\begin{array}{l}\text { International Journal of } \\
\text { Enterprise Network } \\
\text { Management }\end{array}$ & Metal working \\
\hline 17 & (Fliedner) & 2008 & Sustainability: a new lean principle & $\begin{array}{l}\text { Proceedings of the 39th } \\
\text { annual meeting of the } \\
\text { decision sciences } \\
\text { institute, Baltimore, } \\
\text { Maryland }\end{array}$ & Theoretical \\
\hline
\end{tabular}




\begin{tabular}{|c|c|c|c|c|c|}
\hline No & Author/s & Year & Title & $\begin{array}{l}\text { Journal / Conference } \\
\text { proceedings }\end{array}$ & Industrial area of application \\
\hline 18 & (D'Errico et al.) & 2009 & $\begin{array}{l}\text { A New Integrated Lean Manufacturing Model for Magnesium } \\
\text { Products. }\end{array}$ & $\begin{array}{l}\text { JOM-The Journal of The } \\
\text { Minerals, Metals \& } \\
\text { Materials Society }\end{array}$ & Metal working industry \\
\hline 19 & $\begin{array}{l}\text { (Bergmiller and } \\
\text { McCright) }\end{array}$ & 2009 & Parallel models for lean and green operations. & $\begin{array}{l}\text { Proceedings of the } 2009 \\
\text { Industrial Engineering } \\
\text { Research Conference, } \\
\text { Miami, FL. }\end{array}$ & Theoretical \\
\hline 20 & (Miller et al.) & 2010 & A case study of lean, sustainable manufacturing & $\begin{array}{l}\text { Journal of industrial } \\
\text { engineering and } \\
\text { management }\end{array}$ & Furniture \\
\hline 21 & (Esmemr et al.) & 2010 & $\begin{array}{l}\text { A Simulation for Optimum Terminal Truck Number in a Turkish } \\
\text { Port Based on Lean and Green Concept. }\end{array}$ & $\begin{array}{l}\text { The Asian Journal of } \\
\text { Shipping and Logistics }\end{array}$ & Shipping and logistics \\
\hline 22 & (Mollenkopf et al.) & 2010 & Green, lean, and global supply chains & $\begin{array}{l}\text { Journal of Physical } \\
\text { Distribution \& Logistics } \\
\text { Management }\end{array}$ & Theoretical \\
\hline 23 & (Taubitz) & 2010 & Lean, Green \& Safe & Professional Safety & Theoretical \\
\hline 24 & (Sorli et al.) & 2010 & Applying lean thinking concepts to new product development & $\begin{array}{l}\text { APMS } 2010 \text { International } \\
\text { Conference Advances in } \\
\text { Production Management } \\
\text { Systems Book of } \\
\text { Abstracts } \\
\end{array}$ & Multisectoral \\
\hline 25 & (Carvalho et al.) & 2011 & $\begin{array}{l}\text { Lean, agile, resilient and green: } \\
\text { divergencies and synergies }\end{array}$ & $\begin{array}{l}\text { International Journal of } \\
\text { Lean Six Sigma, }\end{array}$ & Theoretical \\
\hline 26 & (Vinodh et al.) & 2011 & $\begin{array}{l}\text { Tools and techniques for enabling sustainability through lean } \\
\text { initiatives }\end{array}$ & $\begin{array}{l}\text { Clean Technologies and } \\
\text { Environmental Policy }\end{array}$ & Theoretical \\
\hline 27 & (Yang et al.) & 2011 & $\begin{array}{l}\text { Impact of lean manufacturing and environmental management on } \\
\text { business performance: An empirical study of manufacturing firms }\end{array}$ & $\begin{array}{l}\text { International Journal of } \\
\text { Production Economics }\end{array}$ & Multisectoral \\
\hline 28 & $\begin{array}{l}\text { (Bergmiller and } \\
\text { McCright) }\end{array}$ & 2011 & Achieving Total Sustainability by Cleaning Up the Dirty Dozen. & $\begin{array}{l}\text { IIE Annual Conference. } \\
\text { Proceedings }\end{array}$ & Theoretical \\
\hline 29 & (Duarte et al.) & 2011 & $\begin{array}{l}\text { Exploring Lean and Green Supply Chain Performance Using } \\
\text { Balanced Scorecard Perspective }\end{array}$ & $\begin{array}{l}\text { Proceedings of the } 2011 \\
\text { International Conference } \\
\text { on Industrial Engineering } \\
\text { and Operations } \\
\text { Management }\end{array}$ & Theoretical \\
\hline 30 & $\begin{array}{l}\text { (Espadinha-Cruz et } \\
\text { al.) }\end{array}$ & 2011 & $\begin{array}{l}\text { A model for evaluating Lean, Agile, Resilient and Green practices } \\
\text { interoperability in supply chains }\end{array}$ & $\begin{array}{l}\text { IEEE International } \\
\text { Conference on Industrial } \\
\text { Engineering and } \\
\text { Engineering Management }\end{array}$ & Automotive \\
\hline 31 & (Mashaei et al.) & 2011 & Green and lean control of cyclic pallet systems & $\begin{array}{l}\text { IEEE International } \\
\text { Conference on } \\
\text { Automation Science and } \\
\text { Engineering }\end{array}$ & Cyclic pallet system \\
\hline
\end{tabular}




\begin{tabular}{|c|c|c|c|c|c|}
\hline No & Author/s & Year & Title & $\begin{array}{l}\text { Journal / Conference } \\
\text { proceedings }\end{array}$ & Industrial area of application \\
\hline 32 & (Puvanasvaran et al.) & 2011 & $\begin{array}{l}\text { Principles and business improvement initiatives of lean relates to } \\
\text { Environmental Management System }\end{array}$ & $\begin{array}{l}\text { IEEE International } \\
\text { Technology Management } \\
\text { Conference }\end{array}$ & Manufacturing and service \\
\hline 33 & (Song and Liang) & 2011 & $\begin{array}{l}\text { Lean construction implementation and its implication on } \\
\text { sustainability: a contractor's case study }\end{array}$ & $\begin{array}{l}\text { Canadian Journal of Civil } \\
\text { Engineering }\end{array}$ & Construction \\
\hline 34 & (Azevedo et al.) & 2012 & $\begin{array}{l}\text { Influence of green and lean upstream supply chain management } \\
\text { practices on business sustainability. }\end{array}$ & $\begin{array}{l}\text { IEEE Transactions on } \\
\text { Engineering Management }\end{array}$ & Automotive \\
\hline 35 & (Bandehnezhad et al.) & 2012 & $\begin{array}{l}\text { An empirical study on the contribution of lean practices to } \\
\text { environmental performance of the manufacturing firms in northern } \\
\text { region of Malaysia }\end{array}$ & $\begin{array}{l}\text { International Journal of } \\
\text { Value Chain } \\
\text { Management }\end{array}$ & $\begin{array}{l}\text { Multisectoral } \\
\text { (electrical and electronics products, medical devices } \\
\text { producers, automobile products, metals, metal products } \\
\text { and machinery, rubber and plastic products, chemicals } \\
\text { and chemical products, paper and paper products, } \\
\text { textiles products, food products and beverages) }\end{array}$ \\
\hline 36 & (Chahal) & 2012 & $\begin{array}{l}\text { An Advance Lean Production System In Industry To Improve } \\
\text { Flexibility And Quality In manufacturing By Implementation Of } \\
\text { FMS \& Green Manufacturing. }\end{array}$ & $\begin{array}{l}\text { International Journal of } \\
\text { Emerging Technology } \\
\text { and Advanced } \\
\text { Engineering }\end{array}$ & Theoretical \\
\hline 37 & (Cabral et al.) & 2012 & $\begin{array}{l}\text { A decision-making model for Lean, Agile, Resilient and Green } \\
\text { supply chain management. }\end{array}$ & $\begin{array}{l}\text { International Journal of } \\
\text { Production Research }\end{array}$ & Automaker \\
\hline 38 & (Hong et al.) & 2012 & $\begin{array}{l}\text { Benchmarking sustainability practices: evidence from } \\
\text { manufacturing firms. }\end{array}$ & Benchmarking & Manufacturing plants \\
\hline 39 & (Ho) & 2012 & $\begin{array}{l}\text { Global Sustainable Development through the Integrated Lean } \\
\text { Management (Green 5-S) Model for TQM }\end{array}$ & $\begin{array}{l}\text { Nang Yan Business } \\
\text { Journal }\end{array}$ & Theoretical \\
\hline 40 & (Jasti et al.) & 2012 & Lean to green supply chain management: a case study. & $\begin{array}{l}\text { Journal of Environmental } \\
\text { Research and } \\
\text { Development }\end{array}$ & Steel \\
\hline 41 & (Salleh et al.) & 2012 & $\begin{array}{l}\text { Green Lean Total Quality Information Management in Malaysian } \\
\text { Automotive Companies }\end{array}$ & Procedia Engineering & Automotive \\
\hline 42 & $\begin{array}{l}\text { (Bashkite and } \\
\text { Karaulova) }\end{array}$ & 2012 & $\begin{array}{l}\text { Integration of Green thinking into Lean fundamentals by Theory of } \\
\text { Inventive Problems-Solving tools }\end{array}$ & DAAAM International & Theoretical \\
\hline 43 & (Ranky et al.) & 2012 & $\begin{array}{l}\text { Sustainable Lean Six-sigma Green Engineering } \\
\text { System Design Educational Challenges and } \\
\text { Interactive Multimedia Solutions }\end{array}$ & $\begin{array}{l}\text { EEE International } \\
\text { Symposium on } \\
\text { Sustainable Systems and } \\
\text { Technology }\end{array}$ & Education \\
\hline 44 & (Sorli et al.) & 2012 & $\begin{array}{l}\text { Expanding Lean Thinking to the Product and } \\
\text { Process Design and Development within the } \\
\text { Framework of Sustainability }\end{array}$ & $\begin{array}{l}\text { AIP Conference } \\
\text { Proceedings }\end{array}$ & Multisectoral \\
\hline 45 & (Marhani et al.) & 2012 & $\begin{array}{l}\text { Lean Construction: Towards Enhancing Sustainable Construction } \\
\text { in Malaysia }\end{array}$ & $\begin{array}{l}\text { Procedia - Social and } \\
\text { Behavioral Sciences }\end{array}$ & Construction \\
\hline 46 & (Garetti and Taisch) & 2012 & Sustainable manufacturing: trends and research challenges & $\begin{array}{l}\text { Production Planning \& } \\
\text { Control }\end{array}$ & Theoretical \\
\hline
\end{tabular}




\begin{tabular}{|c|c|c|c|c|c|}
\hline No & Author/s & Year & Title & $\begin{array}{l}\text { Journal / Conference } \\
\text { proceedings }\end{array}$ & Industrial area of application \\
\hline 47 & (Marhani et al.) & 2013 & $\begin{array}{l}\text { Sustainability Through Lean Construction Approach: A Literature } \\
\text { Review }\end{array}$ & $\begin{array}{l}\text { Procedia - Social and } \\
\text { Behavioral Sciences }\end{array}$ & Theoretical \\
\hline 48 & (Aguado et al.) & 2013 & $\begin{array}{l}\text { Model of efficient and sustainable improvements in a lean } \\
\text { production system through processes of environmental innovation }\end{array}$ & $\begin{array}{l}\text { Journal of Cleaner } \\
\text { Production }\end{array}$ & Forming tube / metal working \\
\hline 49 & (Diaz-Elsayed et al.) & 2013 & $\begin{array}{l}\text { Assessment of lean and green strategies by simulation of } \\
\text { manufacturing systems in discrete production environments. }\end{array}$ & $\begin{array}{l}\text { CIRP Annals - } \\
\text { Manufacturing } \\
\text { Technology }\end{array}$ & Automotive \\
\hline 50 & $\begin{array}{l}\text { (Duarte and Cruz- } \\
\text { Machado) }\end{array}$ & 2013 & $\begin{array}{l}\text { Modelling lean and green: } \\
\text { a review from business models }\end{array}$ & $\begin{array}{l}\text { International Journal of } \\
\text { Lean Six Sigma }\end{array}$ & Theoretical \\
\hline 51 & (Dües et al.) & 2013 & $\begin{array}{l}\text { Green as the new Lean: how to use Lean practices as a catalyst to } \\
\text { greening your supply chain. }\end{array}$ & $\begin{array}{l}\text { Journal of Cleaner } \\
\text { Production }\end{array}$ & Theoretical \\
\hline 52 & $\begin{array}{l}\text { (Hajmohammad et } \\
\text { al.) }\end{array}$ & 2013 & $\begin{array}{l}\text { Lean management and supply management: their role in green } \\
\text { practices and performance }\end{array}$ & $\begin{array}{l}\text { Journal of Cleaner } \\
\text { Production }\end{array}$ & Manufacturing plants \\
\hline 53 & (Jabbour et al.) & 2013 & $\begin{array}{l}\text { Environmental management and operational performance in } \\
\text { automotive companies in Brazil: the role of human resource } \\
\text { management and lean manufacturing }\end{array}$ & $\begin{array}{l}\text { Journal of Cleaner } \\
\text { Production }\end{array}$ & Automotive \\
\hline 54 & (Leonard) & 2013 & Changing Organizational Space: Green? Or Lean and Mean? & Sociology & $\begin{array}{l}\text { Multisectoral } \\
\text { (private, public, voluntary organizations involved in } \\
\text { education, conservation, IT, management consultancy, } \\
\text { law, architecture, mining, construction and the media) }\end{array}$ \\
\hline 55 & $\begin{array}{l}\text { (Maleki and } \\
\text { Machado) }\end{array}$ & 2013 & $\begin{array}{l}\text { Generic Integration of Lean, Agile, Resilient, and Green Practices } \\
\text { in Automotive Supply Chain }\end{array}$ & $\begin{array}{l}\text { Revista de Management } \\
\text { Comparat International }\end{array}$ & Automotive \\
\hline 56 & (Seay and Narsing) & 2013 & $\begin{array}{l}\text { Transitioning to a lean paradigm: } \\
\text { a model for sustainability in the leasing and rental industries }\end{array}$ & $\begin{array}{l}\text { Academy of Strategic } \\
\text { Management Journal, }\end{array}$ & Auto rental and leasing industry \\
\hline 57 & (Sobral et al.) & 2013 & $\begin{array}{l}\text { Green Benefits From Adopting Lean Manufacturing: A Case Study } \\
\text { From the Automotive Sector }\end{array}$ & $\begin{array}{l}\text { Environmental Quality } \\
\text { Management }\end{array}$ & Automotive \\
\hline 58 & (Wiengarten et al.) & 2013 & $\begin{array}{l}\text { Exploring synergetic effects between investments in environmental } \\
\text { and quality/lean } \\
\text { practices in supply chains }\end{array}$ & $\begin{array}{l}\text { Supply Chain } \\
\text { Management }\end{array}$ & $\begin{array}{l}\text { Multisectoral } \\
\text { (Food and drinks, Textiles, leather goods, wood } \\
\text { products, paper and printing Petroleum, chemicals, } \\
\text { pharmaceuticals, plastics and other man-made fibre } \\
\text { products, primary metals, fabricated metal products } \\
\text { except machinery and transportation, Electronic } \\
\text { equipment, measuring devices and optical equipment, } \\
\text { Transportation equipment, Stone, clay, glass and } \\
\text { concrete,Other) }\end{array}$ \\
\hline 59 & (Wu et al.) & 2013 & $\begin{array}{l}\text { Identification of non-value adding (NVA) activities in precast } \\
\text { concrete installation sites to achieve low-carbon installation }\end{array}$ & $\begin{array}{l}\text { Resources, Conservation } \\
\text { and Recycling }\end{array}$ & Construction \\
\hline 60 & (Zamri et al.) & 2013 & $\begin{array}{l}\text { Green Lean Six Sigma and Financial Performance in Malaysian } \\
\text { Automotive Industry }\end{array}$ & $\begin{array}{l}\text { Business Management } \\
\text { and Strategy }\end{array}$ & Automotive \\
\hline 61 & $\begin{array}{l}\text { (Duarte and Cruz- } \\
\text { Machado) }\end{array}$ & 2013 & Lean and green: a business model framework & $\begin{array}{l}\text { Proceedings of the Sixth } \\
\text { International Conference } \\
\text { on Management Science }\end{array}$ & Theoretical \\
\hline
\end{tabular}




\begin{tabular}{|c|c|c|c|c|c|}
\hline No & Author/s & Year & Title & $\begin{array}{l}\text { Journal / Conference } \\
\text { proceedings }\end{array}$ & Industrial area of application \\
\hline & & & & $\begin{array}{l}\text { and Engineering } \\
\text { Management }\end{array}$ & \\
\hline 62 & (Fercoq et al.) & 2013 & $\begin{array}{l}\text { Combining lean and green in manufacturing: a model of waste } \\
\text { management }\end{array}$ & IFAC Proceedings & Theoretical \\
\hline 63 & (Folinas et al.) & 2013 & $\begin{array}{l}\text { Exploring the Greening of the Food Supply Chain with Lean } \\
\text { Thinking Techniques }\end{array}$ & Procedia Technology & Agri-food \\
\hline 64 & (Banawi and Bilec) & 2014 & $\begin{array}{l}\text { A framework to improve construction processes: Integrating Lean, } \\
\text { Green and Six Sigma. }\end{array}$ & $\begin{array}{l}\text { International Journal of } \\
\text { Construction } \\
\text { Management }\end{array}$ & Construction \\
\hline 65 & $\begin{array}{l}\text { (Besseris and } \\
\text { Kremmydas) }\end{array}$ & 2014 & $\begin{array}{l}\text { Concurrent multi-response optimization of austenitic stainless steel } \\
\text { surface roughness driven by embedded lean and green indicators. }\end{array}$ & $\begin{array}{l}\text { Journal of Cleaner } \\
\text { Production }\end{array}$ & Stainless steel \\
\hline 66 & $\begin{array}{l}\text { (Bhamu and Singh } \\
\text { Sangwan) }\end{array}$ & 2014 & Lean manufacturing: literature review and research issues & $\begin{array}{l}\text { International Journal of } \\
\text { Operations \& Production } \\
\text { Management }\end{array}$ & Theoretical \\
\hline 67 & (Bocken et al.) & 2014 & $\begin{array}{l}\text { A literature and practice review to develop sustainable business } \\
\text { model archetypes. }\end{array}$ & $\begin{array}{l}\text { Journal of Cleaner } \\
\text { Production }\end{array}$ & Theoretical \\
\hline 68 & (Brown et al.) & 2014 & $\begin{array}{l}\text { Sustainable value stream mapping (Sus-VSM) in different } \\
\text { manufacturing system configurations: application case studies. }\end{array}$ & $\begin{array}{l}\text { Journal of Cleaner } \\
\text { Production }\end{array}$ & $\begin{array}{l}\text { Multisectoral } \\
\text { (Satellite dishes , dispenser cathode assembly } \\
\text { Manufacturer contract, dedicated flow shop) }\end{array}$ \\
\hline 69 & (Chaplin and Simon) & 2014 & Lean Six Sigma and marketing: a missed opportunity. & $\begin{array}{l}\text { Journal of Productivity } \\
\text { and Performance } \\
\text { Management }\end{array}$ & Food \\
\hline 70 & (Chiarini) & 2014 & $\begin{array}{l}\text { Sustainable manufacturing-greening processes using specific Lean } \\
\text { Production tools: an empirical observation from European } \\
\text { motorcycle component manufacturers. }\end{array}$ & $\begin{array}{l}\text { Journal of Cleaner } \\
\text { Production }\end{array}$ & Motorcycle components manufacturers \\
\hline 71 & (Dhingra et al.) & 2014 & Does lean mean green? & $\begin{array}{l}\text { Journal of Cleaner } \\
\text { Production }\end{array}$ & Theoretical \\
\hline 72 & $\begin{array}{l}\text { (Faulkner and } \\
\text { Badurdeen) }\end{array}$ & 2014 & $\begin{array}{l}\text { Sustainable Value Stream Mapping (Sus-VSM): methodology to } \\
\text { visualize and assess manufacturing sustainability performance. }\end{array}$ & $\begin{array}{l}\text { Journal of Cleaner } \\
\text { Production }\end{array}$ & $\begin{array}{l}\text { Electronics (Satellite television } \\
\text { dishes) }\end{array}$ \\
\hline 73 & (Pampanelli et al.) & 2014 & A Lean \& Green Model for a production cell & $\begin{array}{l}\text { Journal of Cleaner } \\
\text { Production }\end{array}$ & Automotive \\
\hline 74 & (Wong and Wong) & 2014 & Synergizing an ecosphere of lean for sustainable operations & $\begin{array}{l}\text { Journal of Cleaner } \\
\text { Production }\end{array}$ & Electronics (Semiconductor) \\
\hline 75 & $\begin{array}{l}\text { (Johansson and } \\
\text { Sundin) }\end{array}$ & 2014 & Lean and green product development: two sides of the same coin? & $\begin{array}{l}\text { Journal of Cleaner } \\
\text { Production }\end{array}$ & Theoretical \\
\hline 76 & (Galeazzo et al.) & 2014 & $\begin{array}{l}\text { Lean and green in action: interdependencies and performance } \\
\text { of pollution prevention projects. }\end{array}$ & $\begin{array}{l}\text { Journal of Cleaner } \\
\text { Production }\end{array}$ & $\begin{array}{l}\text { Multisectoral } \\
\text { (Refrigeration and the cooling and water pump } \\
\text { industries) }\end{array}$ \\
\hline 77 & (Marimin et al.) & 2014 & $\begin{array}{l}\text { Value chain analysis for green productivity improvement in the } \\
\text { natural rubber supply chain: a case study }\end{array}$ & $\begin{array}{l}\text { Journal of Cleaner } \\
\text { Production }\end{array}$ & Rubber \\
\hline
\end{tabular}




\begin{tabular}{|c|c|c|c|c|c|}
\hline No & Author/s & Year & Title & $\begin{array}{l}\text { Journal / Conference } \\
\text { proceedings }\end{array}$ & Industrial area of application \\
\hline 78 & (Govindan et al.) & 2014 & $\begin{array}{l}\text { Evaluation of green manufacturing practices using a hybrid } \\
\text { MCDM model combining DANP } \\
\text { with PROMETHEE }\end{array}$ & $\begin{array}{l}\text { International Journal of } \\
\text { Production Research }\end{array}$ & Rubber tyres and tube manufacturing \\
\hline 79 & $\begin{array}{l}\text { (Duarte and Cruz- } \\
\text { Machado) }\end{array}$ & 2014 & $\begin{array}{l}\text { Investigating lean and green supply chain linkages through a } \\
\text { balanced scorecard framework }\end{array}$ & $\begin{array}{l}\text { International Journal of } \\
\text { Management } 80 \text { Science } \\
\text { and Engineering } \\
\text { Management }\end{array}$ & Theoretical \\
\hline 80 & (Folinas et al.) & 2014 & Greening the agrifood supply chain with lean thinking practices & $\begin{array}{l}\text { International Journal of } \\
\text { Agricultural Resources }\end{array}$ & Agri-food sector \\
\hline 81 & (Kurdve et al.) & 2014 & $\begin{array}{l}\text { Lean and green integration into production system models e } \\
\text { experiences from Swedish industry }\end{array}$ & $\begin{array}{l}\text { Journal of Cleaner } \\
\text { Production }\end{array}$ & Automotive \\
\hline 82 & $\begin{array}{l}\text { (Martínez-Jurado and } \\
\text { Moyano-Fuentes) }\end{array}$ & 2014 & $\begin{array}{l}\text { Lean Management, Supply Chain Management and Sustainability: } \\
\text { A Literature Review }\end{array}$ & $\begin{array}{l}\text { Journal of Cleaner } \\
\text { Production }\end{array}$ & Theoretical \\
\hline 83 & (Ogunbiyi et al.) & 2014 & $\begin{array}{l}\text { An empirical study of the impact of lean construction techniques } \\
\text { on sustainable construction in the United Kingdom }\end{array}$ & Construction Innovation & Construction \\
\hline 84 & (Verrier et al.) & 2014 & $\begin{array}{l}\text { Combining organizational performance with sustainable } \\
\text { development issues: the Lean and Green project benchmarking } \\
\text { repository }\end{array}$ & $\begin{array}{l}\text { Journal of Cleaner } \\
\text { Production }\end{array}$ & $\begin{array}{l}\text { Multisectoral (Semi-finished product processing, } \\
\text { transport /logistics/ raw material processing and } \\
\text { packaging) }\end{array}$ \\
\hline 85 & (White and James) & 2014 & $\begin{array}{l}\text { Extension of process mapping } \\
\text { to identify "green waste" }\end{array}$ & Benchmarking & Automotive components \\
\hline 86 & (Williams et al.) & 2014 & Green Sustainability and New Social Media & $\begin{array}{l}\text { Journal of Strategic } \\
\text { Innovation and } \\
\text { Sustainability }\end{array}$ & Theoretical \\
\hline 87 & $\begin{array}{l}\text { (Duarte and Cruz- } \\
\text { Machado) }\end{array}$ & 2014 & $\begin{array}{l}\text { Lean and Green Supply Chain Performance: A Balanced Scorecard } \\
\text { Perspective }\end{array}$ & $\begin{array}{l}\text { Proceedings of the Eighth } \\
\text { International Conference } \\
\text { on Management Science } \\
\text { and Engineering } \\
\text { Management }\end{array}$ & Theoretical \\
\hline 88 & (Amani et al.) & 2015 & $\begin{array}{l}\text { Green-Lean Synergy-Root-Cause Analysis in Food Waste } \\
\text { Prevention. }\end{array}$ & $\begin{array}{l}\text { International Journal on } \\
\text { Food System Dynamics }\end{array}$ & Food sector \\
\hline 89 & (Ball) & 2015 & Low energy production impact on lean flow. & $\begin{array}{l}\text { Journal of Manufacturing } \\
\text { Technology Management }\end{array}$ & $\begin{array}{l}\text { Multisectoral } \\
\text { (Tier } 1 \text { supplier in aerospace, automobile, fast moving } \\
\text { consumer goods) }\end{array}$ \\
\hline 90 & $\begin{array}{l}\text { (Cosimato and } \\
\text { Troisi) }\end{array}$ & 2015 & Green supply chain management. & TQM Journal & Logistics \\
\hline 91 & (Dubey and Ali) & 2015 & $\begin{array}{l}\text { Exploring antecedents of extended supply chain performance } \\
\text { measures. }\end{array}$ & Benchmarking & $\begin{array}{l}\text { Multisectoral } \\
\text { (Paper, Rubber and Plastic ,Metal and Fabricated metal, } \\
\text { Cement ,Auto components ) }\end{array}$ \\
\hline 92 & (Esfandyari et al.) & 2015 & $\begin{array}{l}\text { A Lean Based Overview on Sustainability of Printed Circuit Board } \\
\text { Production Assembly. }\end{array}$ & Procedia CIRP & $\begin{array}{l}\text { Electronic devices } \\
\text { (Printed circuit board assembly services/ electronics) }\end{array}$ \\
\hline
\end{tabular}




\begin{tabular}{|c|c|c|c|c|c|}
\hline No & Author/s & Year & Title & $\begin{array}{l}\text { Journal / Conference } \\
\text { proceedings }\end{array}$ & Industrial area of application \\
\hline 93 & (Fahimnia et al.) & 2015 & $\begin{array}{l}\text { A tradeoff model for green supply chain planning: A leanness- } \\
\text { versus-greenness analysis. }\end{array}$ & Omega & $\begin{array}{l}\text { Multisectoral } \\
\text { (Manufacturer-tanks, cylinders and container } \\
\text { Distribution of a wide range of tanks, high and low- } \\
\text { pressure cylinders and other types of } \\
\text { 84domestic/commercial metal containers) }\end{array}$ \\
\hline 94 & (Garza-Reyes) & 2015 & $\begin{array}{l}\text { Lean and green - a systematic review of the state of the art } \\
\text { literature. }\end{array}$ & $\begin{array}{l}\text { Journal of Cleaner } \\
\text { Production }\end{array}$ & Theoretical \\
\hline 95 & $\begin{array}{l}\text { (Govindan et al., } \\
\text { 2015) }\end{array}$ & 2015 & $\begin{array}{l}\text { Lean, green and resilient practices influence on supply chain } \\
\text { performance: interpretive structural modeling approach }\end{array}$ & $\begin{array}{l}\text { International Journal of } \\
\text { Environmental Science } \\
\text { and Technology }\end{array}$ & Automotive supply chain \\
\hline 96 & (Ho et al.) & 2015 & $\begin{array}{l}\text { Applicability of SIRIM Green 5-S Model for productivity \& } \\
\text { business growth in Malaysia }\end{array}$ & TQM Journal & $\begin{array}{l}\text { Multisectoral } \\
\text { (fabricated metal, machinery, electronics } \\
\text { medical/optical, automotive) }\end{array}$ \\
\hline 97 & (Kurdve et al.) & 2015 & $\begin{array}{l}\text { Waste flow mapping to improve sustainability of waste } \\
\text { management: a case study approach }\end{array}$ & $\begin{array}{l}\text { Journal of Cleaner } \\
\text { Production }\end{array}$ & Automotive \\
\hline 98 & (Ng et al.) & 2015 & $\begin{array}{l}\text { Integrating and implementing Lean and Green practices based on } \\
\text { proposition of Carbon-Value Efficiency metric }\end{array}$ & $\begin{array}{l}\text { Journal of Cleaner } \\
\text { Production }\end{array}$ & Metal stamp parts production \\
\hline 99 & (Piercy and Rich) & 2015 & $\begin{array}{l}\text { The relationship between lean operations and } \\
\text { sustainable operations (Piercy and Rich) }\end{array}$ & $\begin{array}{l}\text { Journal of Operations \& } \\
\text { Production Management }\end{array}$ & $\begin{array}{l}\text { Multisectoral } \\
\text { (Cosmetic, pharmaceutical, furniture, FMCG and metal } \\
\text { pressing ) }\end{array}$ \\
\hline 100 & (Wu et al.) & 2015 & $\begin{array}{l}\text { The Impact of Integrated Practices of Lean, Green, and Social } \\
\text { Management Systems on Firm Sustainability Performance-- } \\
\text { Evidence from Chinese Fashion Auto-Parts Suppliers }\end{array}$ & Sustainability & Automobile \\
\hline 101 & (Greinacher et al.) & 2015 & $\begin{array}{l}\text { Simulation Based Assessment of Lean and Green Strategies in } \\
\text { Manufacturing Systems }\end{array}$ & Procedia CIRP & Metal \\
\hline 102 & $\begin{array}{l}\text { (Hartini and } \\
\text { Ciptomulyono) }\end{array}$ & 2015 & $\begin{array}{l}\text { The Relationship between Lean and Sustainable Manufacturing on } \\
\text { Performance: Literature Review }\end{array}$ & Procedia Manufacturing & Theoretical \\
\hline
\end{tabular}

